\title{
Hydroclimate Responses over Global Monsoon Regions Following Volcanic Eruptions at Different Latitudes $\mathscr{O}$
}

\author{
MENG ZUO AND TIANJUN ZHOU ${ }^{\mathrm{a}}$ \\ State Key Laboratory of Numerical Modeling for Atmospheric Sciences and Geophysical Fluid Dynamics (LASG), Institute of \\ Atmospheric Physics, Chinese Academy of Sciences, and University of Chinese Academy of Sciences, Beijing, China \\ WENMIN MAN ${ }^{\mathrm{a}}$ \\ State Key Laboratory of Numerical Modeling for Atmospheric Sciences and Geophysical Fluid Dynamics (LASG), \\ Institute of Atmospheric Physics, Chinese Academy of Sciences, Beijing, China
}

(Manuscript received 23 October 2018, in final form 18 March 2019)

\begin{abstract}
Understanding the influence of volcanic eruptions on the hydroclimate over global monsoon regions is of great scientific and social importance. However, the link between the latitude of volcanic eruptions and related hydroclimate changes over global monsoon regions in the last millennium remains inconclusive. Here we show divergent hydroclimate responses after different volcanic eruptions based on large sets of reconstructions, observations, and climate model simulation. Both the proxy and observations show that Northern Hemispheric (Southern Hemispheric) monsoon precipitation is weakened by northern (southern) and tropical eruptions but is enhanced by the southern (northern) eruptions. A similar relationship is found in coupled model simulations driven by volcanic forcing. The model evidence indicates that the dynamic processes related to changes in atmospheric circulation play a dominant role in precipitation responses. The dry conditions over the Northern Hemisphere (Southern Hemisphere) and global monsoon regions following northern (southern) and tropical eruptions are induced through weakened monsoon circulation. The wet conditions over Northern Hemispheric (Southern Hemispheric) monsoon regions after southern (northern) eruptions are caused by the enhanced cross-equator flow. We extend our model simulation analysis from mean state precipitation to extreme precipitation and find that the response of the extreme precipitation is consistent with that of the mean precipitation but is more sensitive over monsoon regions. The response of surface runoff and net primary production is stronger than that of precipitation over some submonsoon regions. Our results imply that it is imperative to consider the potential volcanic eruptions at different hemispheres in the design of near-term decadal climate prediction experiments.
\end{abstract}

\section{Introduction}

Volcanic eruptions are one of the most important natural causes of climate change and have major impacts on the global hydroclimate (Robock 2000, 2007; Timmreck 2012). The injection of sulfate aerosols decreases the

\footnotetext{
Supplemental information related to this paper is available at the Journals Online website: https://doi.org/10.1175/JCLI-D-180707.s1.

${ }^{a}$ Additional affiliation: CAS Center for Excellence in Tibetan Plateau Earth Sciences, Chinese Academy of Sciences, Beijing, China.
}

Corresponding author: Tianjun Zhou, zhoutj@lasg.iap.ac.cn surface downward shortwave radiation, cooling the surface temperature and suppressing the global hydrological cycle (Grinsted et al. 2007; Trenberth and Dai 2007; Iles et al. 2013). Monsoon precipitation imposes great impacts on society since it affects over two-thirds of the world's population. Knowledge of the hydroclimate response to volcanic eruptions over monsoon regions is crucial for adaptation. Volcanic eruptions result in decreased global precipitation, runoff, extreme precipitation, and evapotranspiration (Oman et al. 2006; Iles et al. 2013; Iles and Hegerl 2015; Paik and Min 2017, 2018), which may trigger drought events in some regions such as eastern China (Shen et al. 2007, 2008; Peng et al. 2010). The weakening of monsoon circulation over Asia, the Americas, and Africa is observed and simulated after volcanic eruptions, mainly through a reduction in moisture and 
land-sea thermal contrast (Anchukaitis et al. 2010; Man et al. 2014; Wegmann et al. 2014; Colose et al. 2016; Dogar et al. 2017). The responses of precipitation to volcanic eruptions over climatologically wet and dry regions varywet gets drier and dry gets wetter, which is opposite to the response under global warming (Held and Soden 2006; Iles et al. 2013; Iles and Hegerl 2014, 2015).

Most studies focused on the impacts of tropical eruptions, the high-latitude eruptions also result in a reduction of monsoon precipitation and circulation (Schneider et al. 2009). When comparing the hydrological response to volcanic eruptions at different latitudes, several studies indicate that the volcanic eruptions in the Southern Hemisphere ( $\mathrm{SH}$ ) would increase the monsoon precipitation in the Northern Hemisphere (NH) (Haywood et al. 2013; Zhuo et al. 2014; Liu et al. 2016). Observational evidence shows that asymmetric stratospheric aerosol concentrated in the $\mathrm{NH}$ is a precursor of Sahelian drought, whereas those concentrated in the SH induces a greening of the Sahel, resulting from changes in the Atlantic sea surface temperature (SST) gradient (Haywood et al. 2013). Two independent drought and volcanic reconstructions reveal a drying (wetting) trend over China following $\mathrm{NH}(\mathrm{SH})$ volcanic aerosol injections (Zhuo et al. 2014). Model simulation further showed that the global monsoon precipitation in one hemisphere is enhanced by the remote volcanic forcing occurring in the other hemisphere through circulation change (Liu et al. 2016). Proxy and model simulations reveal that volcanic eruptions may increase the likelihood of El Niño (Adams et al. 2003; Mann et al. 2005), which appears to amplify the hydroclimate signature following volcanic eruptions (Stevenson et al. 2016).

A previous study showed precipitation responses over global monsoon region to different volcanic eruptions (Liu et al. 2016), but they used only one ensemble member and the result is partly contaminated by internal variability. From a modeling perspective, ensemble simulations are the most suited method to study volcano-forced responses (Zanchettin et al. 2012; Pausata et al. 2015; Stevenson et al. 2017). Moreover, mainly the proxy data over the Asian monsoon region are used in Liu et al. (2016) and no sufficient reconstructions in other monsoon regions are used. More efforts should be devoted to interpreting and comparing the response of hydroclimate over global monsoon regions to volcanic eruptions at different latitudes based on both large sets of proxies and ensemble simulations. In addition, previous studies generally focused on the mean precipitation response, and less attention was paid to extreme precipitation and other hydrological factors. The extreme temperature and precipitation responses over the global land to five explosive tropical volcanic eruptions since the 1880s were investigated based on CMIP5 models (Paik and Min 2018). The results revealed a robust reduction in extreme and mean precipitation after eruptions, but they only focused on the latest five volcanic eruptions since the 1880 s, which are weak in intensity. In addition, the model simulations include both solar and volcanic forcing and thus the specific influence of volcanic forcing cannot be solely distinguished. To reveal the responses of climate extremes to volcanic eruptions, there are urgent needs for the use of a single volcano forcing experiment and selecting volcanic eruptions with higher intensity in the last millennium. In addition, barely any study has quantified the contributions of thermodynamic factors in association with changes in specific humidity and dynamic factors due to changes in atmospheric circulation to the precipitation changes after eruptions, which are crucial for assessing the potential risks associated with future large volcanic eruptions.

In this investigation, we analyze the different hydroclimate responses to northern, tropical, and southern volcanic eruptions over the global monsoon regions based on reconstructions, instrumental data, and the Community Earth System Model Last Millennium Ensemble (CESM-LME) simulation, which has the largest ensemble of LM simulations and provides ensembles of simulations with each forcing individually. Based on proxy data, instrumental data, model data comparison, and physical processes diagnosis, we aim to answer the following questions: 1) What are the hydroclimate responses following northern, tropical, and southern volcanic eruptions based on reconstructions and instrumental data? What are the differences between them? 2) What are the consistencies between model simulations and reconstructions/observations? 3) How does the different response mechanism arise due to differences in the volcanic forcing structure?

The remainder of the paper is organized as follows. Section 2 provides a description of the datasets, methods, model, as well as the criteria for volcano selection. Section 3 presents the results. The conclusions are given in section 4.

\section{Datasets, methods, and model simulation}

\section{a. Proxy and instrumental data}

The datasets used in this study include

1) the Monsoon Asia Drought Atlas (MADA), a seasonally resolved gridded spatial reconstruction of Asian monsoon drought and pluvials over the past millennium (1300-2005) derived from tree-ring chronologies (Cook et al. 2010),

2) 530-yr multiproxy May-September precipitation field reconstructions over China (Shi et al. 2017), 
3) a gridded reconstruction of annual May-September precipitation from 1470 to 1999 for the Asian monsoon region (Feng et al. 2013),

4) southeastern Tibetan Plateau April-June selfcalibrating Palmer drought severity index (scPDSI) for the past 500 years, based on two Abies forestii tree-ring chronologies from the southern Shaluli Mountains (Li et al. 2017),

5) spatially and temporally highly resolved gridded reconstruction of precipitation over southern South America (Neukom et al. 2010), with summer and winter reconstructions back to 1498 and 1590 , respectively,

6) southern Africa 200-yr multiproxy summer and winter precipitation reconstructions (Neukom et al. 2014),

7) north-central China 400-yr precipitation reconstructions (Yi et al. 2010),

8) Mexican Drought Atlas (MXDA) 600-yr scPDSI reconstructions (Stahle et al. 2016),

9) reconstructed October-September Queensland rainfall from coral luminescence from 25 coral cores (1631-2005; Lough 2007);

10) monthly mean precipitation data from the Global Precipitation Climatology Project (GPCP) data, version 2.2, from 1979 to 2010 (used to define the global monsoon regions in the observation; Huffman et al. 2009), and

11) monthly mean precipitation data from the Global Precipitation Climatology Centre (GPCC) data from 1901 to 2013 (Schneider et al. 2014).

\section{b. Model data}

The model data used in this study are from CESMLME, which employs version 1.1 of CESM with the Community Atmosphere Model, version 5 (Hurrell et al. 2013). CESM-LME uses $\sim 2^{\circ}$ resolution in its atmosphere and land components and $\sim 1^{\circ}$ resolution in its ocean and sea ice components. This model provides the largest ensemble of LM simulations currently available (Otto-Bliesner et al. 2016). The simulations are forced by insolation, volcanic eruptions, land use, greenhouse gases, and orbital forcing. The only differences between the ensemble members are due to different perturbations of the initial states of the air temperature field. For volcanic forcing, LME uses version 1 of the Gao et al. (2008) ice-core-derived reconstruction, which is based on volcanic deposition signals from 54 ice-core records from both the Arctic and Antarctica, as an estimate of aerosol loadings as a function of latitude, altitude, and month. Stratospheric aerosols are designed to be distributed in three layers in the lower stratosphere, and are subject to a single size distribution. Our analysis is based on the outputs of the volcanic forcing ensemble
TABLE 1. List of eruption years for northern, tropical, and southern volcanic eruption classes in the CESM-LME simulation.

\begin{tabular}{ll}
\hline \hline \multicolumn{1}{c}{ Class } & \multicolumn{1}{c}{ Years } \\
\hline Northern & $1176,1213,1600,1641,1762$, and 1835 \\
Tropical & $1001,1258,1284,1416,1809,1815$, and 1991 \\
Southern & 1275,1341, and 1452 \\
\hline
\end{tabular}

(five members). We constructed multimember means by averaging over all five volcanic-only forcing runs. CESM LME experiments can reasonably reproduce the observed global monsoon region and global monsoon intensity (Fig. S1 in the online supplemental material) and have reasonable performance in simulating the thermodynamic and dynamic response to volcanic eruptions (Stevenson et al. 2016; Prado et al. 2018; Yan et al. 2018; Zuo et al. 2018). This adds confidence to our study of global monsoon response to volcanic eruptions based on the CESM LME experiments.

\section{c. Criteria for volcano selection}

The volcanic eruptions are divided into three types according to the distributions of volcanic aerosols in the Northern and Southern Hemispheres, as computed by Gao et al. (2008). Volcanic eruptions are classed by the ratio of Northern to Southern Hemisphere stratospheric aerosol loading over the course of eruption following Stevenson et al. (2016). When selecting these volcanic eruptions in model simulation, we use the volcanic forcing data in CESM-LME and select the volcanic eruptions that reach their peaks at the same time to remove the impact of eruption season (Stevenson et al. 2017). For the simulation period (850-2005), the eruptions whose intensity exceeds the average and reach the peak values at the same time are selected (Table 1). The mean volcanic intensity is defined by the average mean global total sulfate aerosol injection for all years when aerosol injection is not zero. Different critical values do not change the results qualitatively. We select volcanic eruptions in reconstruction and observation data based on the same volcanic forcing reconstructed by Gao et al. (2008); in this way the volcano stratification can be consistent in both simulation and reconstruction/observation analyses. For different time periods of reconstruction and instrumental data, we use lower thresholds of 5 and $3 \mathrm{Tg}$, respectively, to include more volcanic events (Table 2).

\section{d. Analysis methods}

Following Wang et al. (2012), the global monsoon domains is defined by the regions in which the local summerminus-winter precipitation rate exceeds $2.0 \mathrm{~mm}^{-1}$ day $^{-1}$ and the local summer precipitation exceeds $55 \%$ of the annual total. The local summer (May-September) is 
TABLE 2. List of eruption years for northern, tropical, and southern volcanic eruption classes in the instrumental dataset (event years that occur during or near known El Niño years are shown in boldface).

\begin{tabular}{ll}
\hline \hline Class & \multicolumn{1}{c}{ Years } \\
\hline Northern & 1912, 1925, 1943, 1976, and $\mathbf{1 9 8 2}$ \\
Tropical & $\mathbf{1 9 6 3}$ and $\mathbf{1 9 9 1}$ \\
Southern & 1902 \\
\hline
\end{tabular}

denoted as MJJAS for the NH and (November-March) as NDJFM for the SH. In this study, we define the global monsoon region based on the 1979-2010 climatology from the GPCP data, version 2.2 (Huffman et al. 2009). The global monsoon area is shown in supplemental Fig. S2. When we do the area average, we calculate precipitation and extreme precipitation over monsoon region including land and ocean grids. For surface runoff and net primary production (NPP), regional mean is calculated over global land monsoon regions since the output data of these two variables only cover land region. Since the global monsoon is dominated by the land area, calculating the response of precipitation and extreme precipitation over the global land monsoon area will not change the results qualitatively (figure not shown).

The superposed epoch analysis (SEA) method is used to evaluate the influence of explosive volcanoes on global monsoon precipitation anomalies (Haurwitz and Brier 1981). The year in which the volcanic aerosol mass peaks is regarded as year 0 , and the following year is named as year 1 . We focus on the hydroclimate response in the first local summer [MJJAS of year 1 for the $\mathrm{NH}$ monsoon region; November and December (year 0) and January-March (year 1) for the SH monsoon region], which is calculated with respect to a 5-yr pre-eruption mean (Fischer et al. 2007; Iles et al. 2013). And we normalize the data in the event windows to avoid the possibility that any single eruption would dominate the epoch signal (Adams et al. 2003; Anchukaitis et al. 2010), and we retain the original units. The significance of the response to volcanic eruptions was assessed using a Monte Carlo method.

Some eruptions occur during or near known El Niño years; previous studies reveal El Niño-like SST anomalies after volcanic eruptions based on model simulations and proxy data (Adams et al. 2003; D'Arrigo et al. 2009; Liu et al. 2018a,b; Zuo et al. 2018). Observational SST datasets indicate an El Niño-like pattern after four out five volcanic eruptions since 1882, which is a small sample and a warm event was already underway during two of these eruptions (Khodri et al. 2017). Therefore, removing the influence of El Niño in observation makes the response of precipitation to volcanic eruptions more clear and avoids confusing it with ENSO variability. To minimize the influence of ENSO in the observed data, we used a linear regression method: $y^{\prime}=y-r(\mathrm{CTI}, y) \times$ CTI, where $y^{\prime}$ is ENSO-independent climate field and $r$ is the regression coefficient of winter ENSO index-cold tongue index (CTI) - onto climate fields (Iles et al. 2013). We did not remove the ENSO signal in the reconstruction since there is a large uncertainty among different ENSO proxies (McGregor et al. 2010). Following Iles and Hegerl (2014), the multimember ensemble mean technique is an effective way to extract the forced signal and remove the internal variability including ENSO. This is further confirmed by our comparison of results with and without removing the ENSO signals (See Fig. S3 in the online supplemental information).

\section{e. Moisture budget analysis}

To understand the mechanism of changes in precipitation over global monsoon regions following volcanic eruptions, a moisture budget analysis (Chou et al. 2009 ) is employed in this study. The vertically integrated anomalous moisture equation is written as

$$
\partial_{t}\langle q\rangle^{\prime}+\left\langle\mathbf{u} \cdot \nabla_{h} q\right\rangle^{\prime}+\left\langle\omega \partial_{p} q\right\rangle^{\prime}=E^{\prime}-P^{\prime},
$$

where the angle brackets denote the mass integral through the entire atmospheric column and the primes denote the monthly anomaly with the climatological annual cycle removed. Variable $q$ represents specific humidity; $\mathbf{u}$ and $\omega$ denote horizontal wind and vertical pressure velocity, respectively; and $E$ and $P$ denote evaporation and precipitation, respectively. On the interannual time scale, the term $\partial_{t}\langle q\rangle^{\prime}$ is negligible since it is far smaller than the other terms. Therefore, the changes in precipitation can be expressed as

$$
P^{\prime}=-\left\langle\omega \partial_{p} q\right\rangle^{\prime}-\langle V \cdot \nabla q\rangle^{\prime}+E^{\prime}+\text { residual, }
$$

where $\left\langle\omega \partial_{p} q\right\rangle^{\prime}$ represents vertical moisture advection and $\left\langle V_{h} \cdot \nabla q\right\rangle^{\prime}$ represents horizontal moisture advection, which can be further divided into the thermodynamic and dynamic terms as the following formulas show:

$$
\begin{gathered}
-\left\langle\omega \partial_{p} q\right\rangle^{\prime}=-\left\langle\bar{\omega} \partial_{p} q^{\prime}\right\rangle-\left\langle\omega^{\prime} \partial_{p} \bar{q}\right\rangle-\left\langle\omega^{\prime} \partial_{p} q^{\prime}\right\rangle \text { and } \\
-\left\langle V_{h} \cdot \nabla q\right\rangle^{\prime}=-\left\langle\overline{V_{h}} \cdot \nabla q^{\prime}\right\rangle-\left\langle V_{h}^{\prime} \cdot \nabla \bar{q}\right\rangle-\left\langle V_{h}^{\prime} \cdot \nabla q^{\prime}\right\rangle .
\end{gathered}
$$

The dynamic terms are $-\left\langle\omega^{\prime} \partial_{p} \bar{q}\right\rangle$ and $-\left\langle V_{h}^{\prime} \cdot \nabla \bar{q}\right\rangle$; the thermodynamic terms are $-\left\langle\bar{\omega} \partial_{p} q^{\prime}\right\rangle$ and $-\left\langle\overline{V_{h}} \cdot \nabla q^{\prime}\right\rangle$. The vertical integral angle brackets denote a mass integration through the troposphere with $p_{T}$ as the depth of the troposphere: 


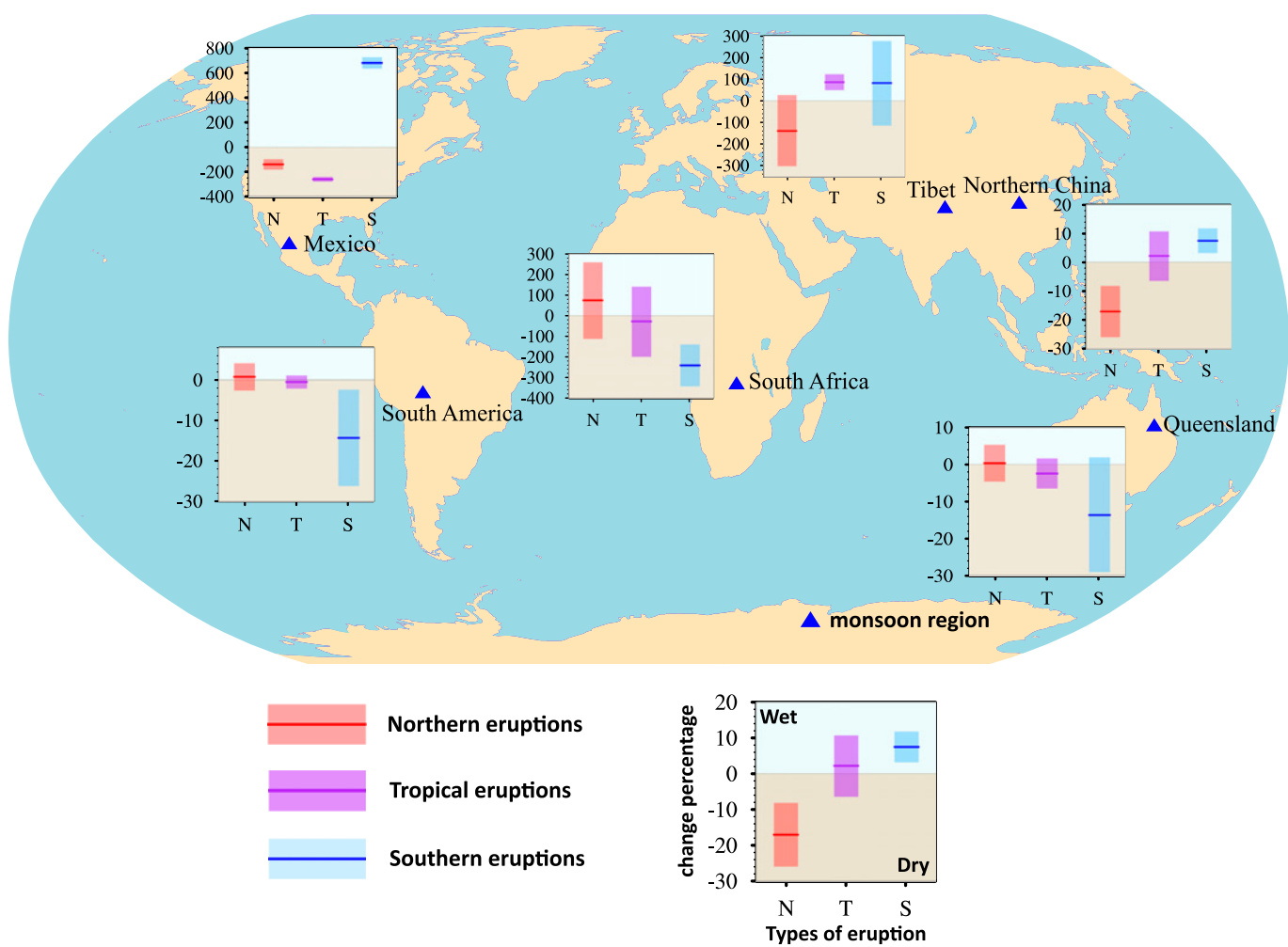

FIG. 1. Reconstructed hydroclimate response to northern, tropical, and southern volcanic eruptions in the first local summer over monsoon regions, expressed as percentage changes relative to the climatology (\%): PDSI response over Mexico; PDSI response over the southeastern Tibetan Plateau; precipitation response over northern China; precipitation response over South America; precipitation response over South Africa; and precipitation response over Queensland. The red, purple, and blue bars represent anomalies averaged over monsoon regions after northern, tropical, and southern volcanic eruptions. Thick lines show the multieruption mean, and the shading represents the spread between each volcanic eruption. The blue triangles represent monsoon regions.

$$
\langle X\rangle=g^{-1} \int_{p_{s}}^{p_{s}-p_{T}} X d p
$$

\section{f. Moist static energy budget analysis}

In the tropics, vertical motion is constrained by the moist static energy (MSE) budget (Neelin and Held 1987; Wu et al. 2017). We diagnosed the MSE equation for the global monsoon regions. Following Neelin (2007), the MSE equation can be written as

$\partial_{t}\left\langle C_{p} T+L_{v} q\right\rangle^{\prime}+\left\langle\mathbf{u} \cdot \nabla_{h}\left(C_{p} T+L_{v} q\right)\right\rangle^{\prime}+\left\langle\omega \partial_{p} h\right\rangle^{\prime}=F_{\text {net }}^{\prime}$

MSE is denoted by $h=C_{p} T+L_{v} q+\phi ; T$ denotes air temperature; $\phi$ represents geopotential height; $C_{p}$ and $L_{v}$ represent the specific heat at constant pressure and the latent heat of vaporization, respectively; and $C_{p} T+$ $L_{v} q$ is the moist enthalpy. The net MSE flux coming into the atmospheric column from the surface and the top of atmosphere is denoted by $F_{\text {net }}$, which is equal to $F_{\text {net }}=F_{t}-F_{s}$. The net heat flux at the top of the atmosphere (TOA) is $F_{t}=S_{t}^{\downarrow}-S_{t}^{\uparrow}-R_{t}^{\uparrow}$, the net heat flux at the surface is $F_{s}=S_{s}^{\downarrow}-S_{s}^{\uparrow}+R_{s}^{\downarrow}-R_{s}^{\uparrow}-\mathrm{LH}-\mathrm{SH}$, subscripts $s$ and $t$ on the shortwave $\left(S^{\uparrow}\right.$ and $\left.S^{\downarrow}\right)$ and longwave $\left(R^{\uparrow}\right.$ and $\left.R^{\downarrow}\right)$ radiative terms denote surface and TOA, and LH and SH are latent heat flux and sensible heat flux, respectively. Positive $F_{t}$ and $F_{s}$ indicate downward heat fluxes.

Similar to the moisture equation, the MSE equation can be simplified to

$$
\begin{aligned}
\left\langle\omega^{\prime} \partial_{p} \bar{h}\right\rangle \approx & F_{\mathrm{net}}^{\prime}-\left\langle\overline{\mathbf{u}} \cdot \nabla_{h}\left(C_{p} T+L_{v} q\right)^{\prime}\right\rangle \\
& -\left\langle\mathbf{u}^{\prime} \cdot \nabla_{h} \overline{\left(C_{p} T+L_{v} q\right)}\right\rangle-\left\langle\bar{\omega} \partial_{p} h^{\prime}\right\rangle+\mathrm{NL},
\end{aligned}
$$

in which NL represents the sum of all of the nonlinear terms. 

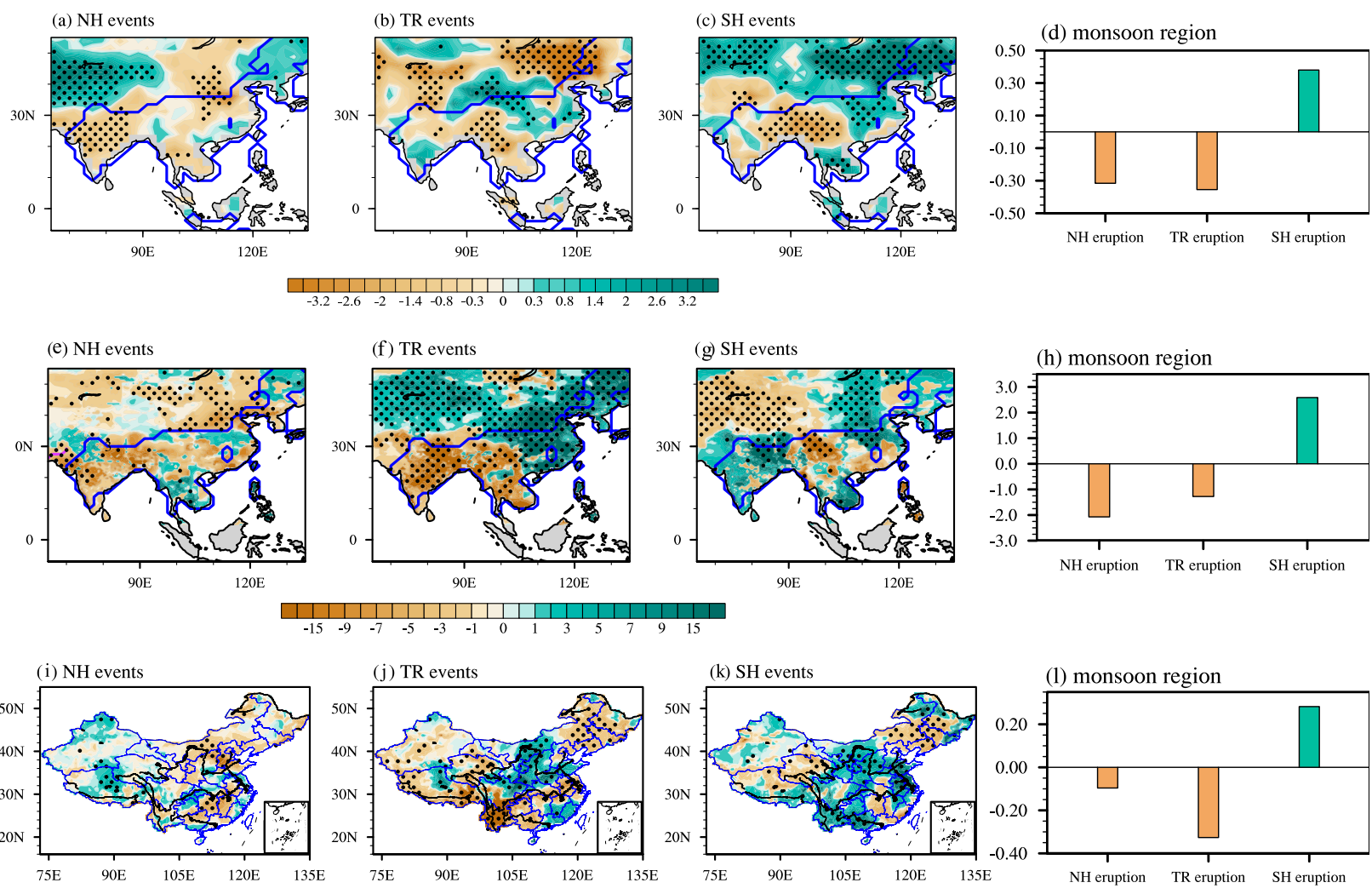

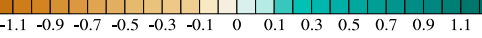

FIG. 2. Reconstructed PDSI and precipitation anomalies in the first boreal summer over Asia following northern, tropical, and southern volcanic eruptions: PDSI response to (a) northern, (b) tropical, and (c) southern eruptions based on the MADA PDSI and (d) the corresponding PDSI anomalies averaged over monsoon regions following northern, tropical, and southern eruptions; warm-season precipitation response to (e) northern, (f) tropical, and (g) southern eruptions over China based on the reconstruction by Feng et al. (2013) and (h) the corresponding averaged precipitation response to northern, tropical, and southern eruptions over monsoon regions $\left(\mathrm{mm} \mathrm{day}^{-1}\right)$; and May-September precipitation response to (i) northern, (j) tropical, and (k) southern eruptions over China based on the reconstruction by Shi et al. (2017) and (1) the corresponding averaged precipitation response to northern, tropical, and southern eruptions over monsoon regions $\left(\mathrm{mm} \mathrm{day}^{-1}\right)$. The significance levels are determined according to the Monte Carlo test, and the values that are significant at the $90 \%$ confidence level are dotted. The green and brown bars represent anomalies averaged over monsoon regions. The blue lines represent monsoon regions.

In the monsoon regions with deep convection, the vertical profile of $\omega^{\prime}$ shows a top-heavy bow structure with a maximum at approximately $500 \mathrm{hPa}$, suggesting that it is dominated by the deep mode of the tropical vertical motion (Back and Bretherton 2009).
Meanwhile, the vertical profile of climatological MSE $\bar{h}$ shows a bottom-heavy bow structure with a maximum at $700 \mathrm{hPa}$. The ascending motion of the vertical profile of the deep mode tends to export the MSE out of the atmospheric column in the tropics, causing

TABLE 3. The number of volcanoes used for each proxy data and the time period of each reconstruction (here, TR indicates tropical).

\begin{tabular}{|c|c|c|c|c|}
\hline \multirow[b]{2}{*}{ Reconstructions } & \multicolumn{3}{|c|}{ No. of volcanic eruptions } & \multirow[b]{2}{*}{ Time period } \\
\hline & NH & TR & $\mathrm{SH}$ & \\
\hline PDSI over Mexico & 9 & 5 & 6 & $1400-2012$ \\
\hline $\begin{array}{l}\text { PDSI over the southeastern Tibetan } \\
\text { Plateau }\end{array}$ & 7 & 4 & 6 & 1498-2013 \\
\hline Precipitation over northern China & 5 & 4 & 4 & 1600-2000 \\
\hline Precipitation over South America & 7 & 3 & 6 & $1498(1590)-1995$ \\
\hline Precipitation over South Africa & 5 & 3 & 3 & 1796-1996 \\
\hline Precipitation over Queensland & 5 & 4 & 4 & $1631-1983$ \\
\hline
\end{tabular}


(a) $\mathrm{NH}$ events $\quad$ GPCC $y r+1$ MJJAS

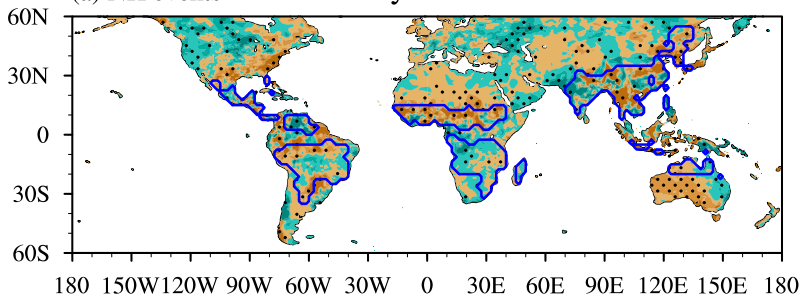

(c) TR events

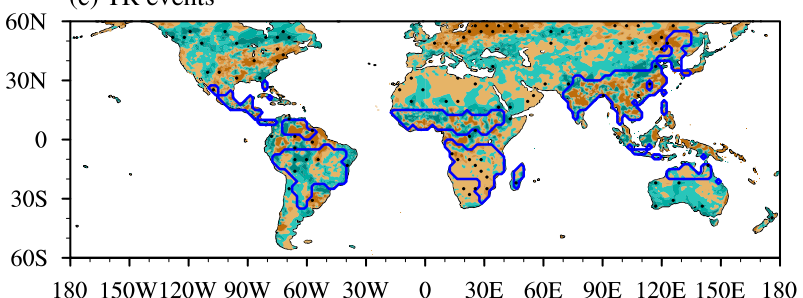

(e) $\mathrm{SH}$ events

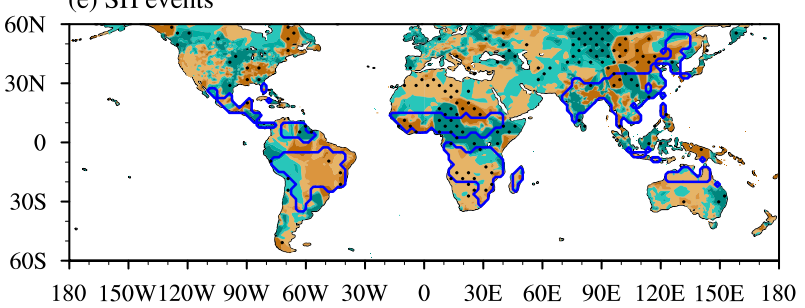

(b) NH events $\quad$ GPCC yr+1 NDJFM

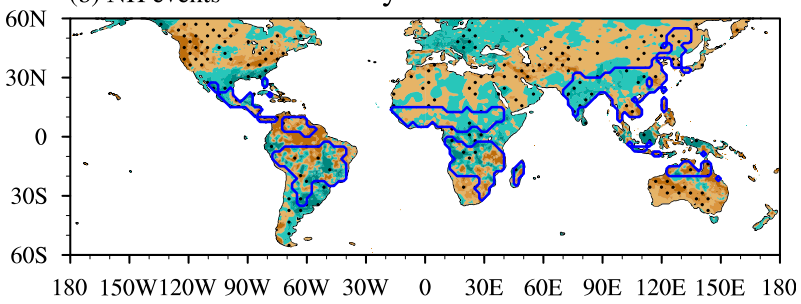

(d) TR events

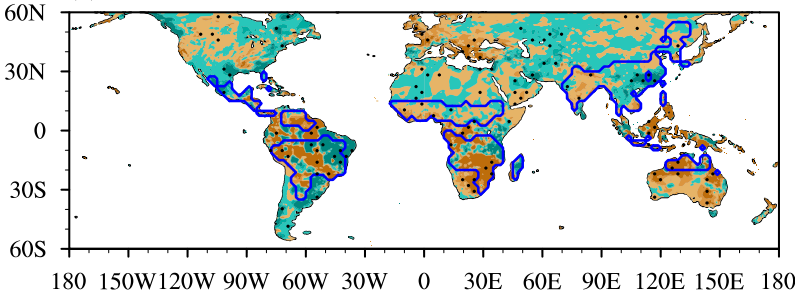

(f) $\mathrm{SH}$ events

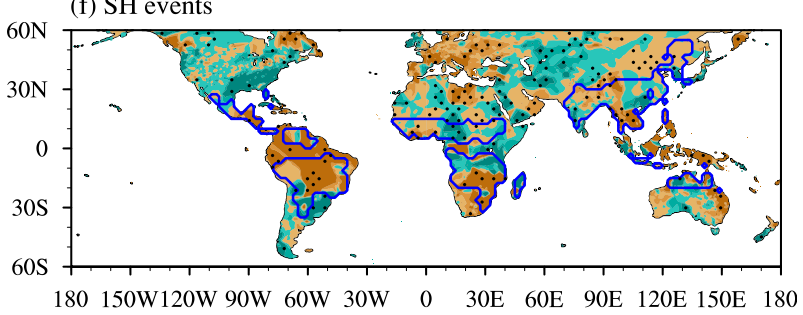

$\begin{array}{lllll}-0.6 & -0.3 & 0 & 0.3 & 0.6\end{array}$

FIG. 3. Precipitation $\left(\mathrm{mm} \mathrm{day}^{-1}\right.$ ) anomalies in the first (left) boreal summer (MJJAS) and (right) boreal winter (NDJFM) following (a),(b) northern, (c),(d) tropical, and (e),(f) southern volcanic eruptions in the GPCC dataset based on instrumental data (with ENSO influence removed). The significance levels are determined according to the Monte Carlo test, and the values that are significant at the $90 \%$ confidence level are dotted. The blue lines represent monsoon regions.

positive gross moisture stability of the column (Back and Bretherton 2009). If the physical processes on the right-hand side of the above equation tend to reduce (increase) the MSE in the column, descending (ascending) anomalies should be generated to decrease (increase) the MSE exported out of the column to keep the MSE budget balance (Wu et al. 2017).

\section{Results}

In the following analysis, we first present the hydroclimate responses to volcanic eruptions at different latitudes over global monsoon regions based on reconstructions, instrumental data and model simulation. Next, we reveal the underlying mechanisms of the divergent hydroclimate responses to different types of eruptions based on some quantitative diagnostic methods.

\section{a. Hydroclimate response in reconstructed proxy data}

To reveal the hydroclimate response to northern, tropical, and southern volcanic eruptions over monsoon regions, we collect large sets of proxy data including the Palmer drought severity index (PDSI) and precipitation over the global monsoon regions. We found an overall dry (wet) anomaly in NH monsoon regions in the first boreal summer following northern (southern) eruptions (Fig. 1), manifested in the hydroclimate response over northern China, the southeastern Tibetan Plateau, and Mexico. Over the SH monsoon regions located in Queensland, South Africa, and South America, dry (wet) anomalies are observed in the first austral summer after southern (northern) eruptions. The above results show a clear divergent hydroclimate response to different volcanic eruptions based on a large number of reconstructions over global monsoon regions-monsoon precipitation in one hemisphere is enhanced (reduced) by the volcanic forcing occurring in the other (same) hemisphere.

We further examine the changes of other records over the densely populated monsoon regions of Asia and China and find similar responses. Based on the MADA PDSI reconstructions, drier conditions are 


\section{Pre \& UV850}

(a)NH events (MJJAS+1)

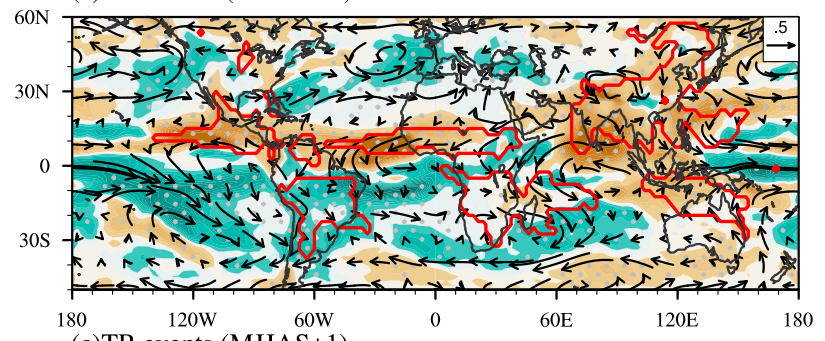

(c)TR events (MJJAS+1)

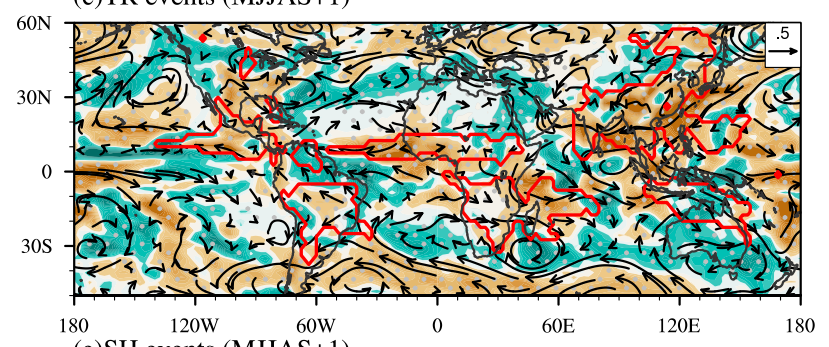

(e)SH events (MJJAS+1)

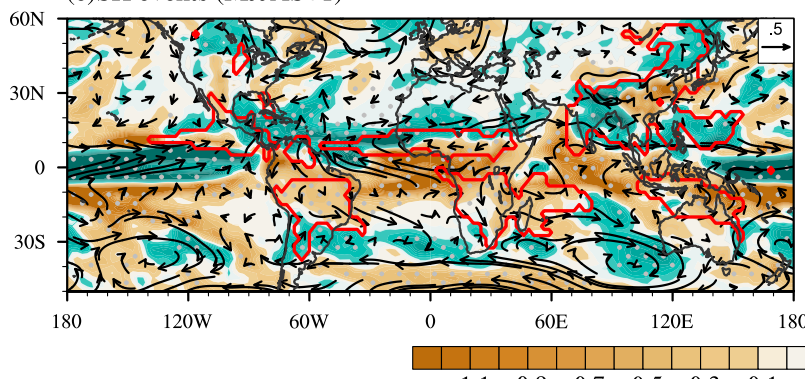

(b) NH events (NDOJFM+1)

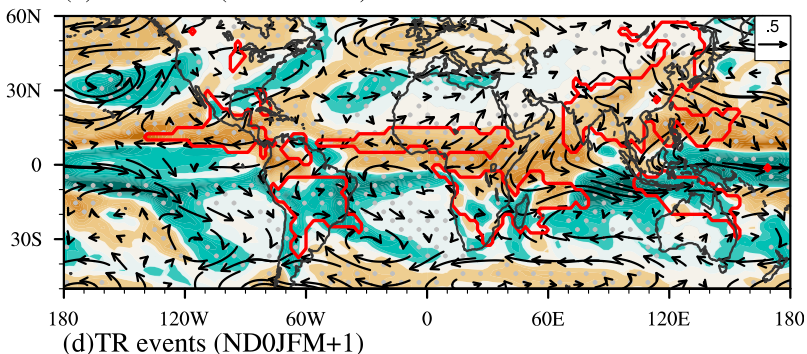

(d)TR events (ND0JFM+1)

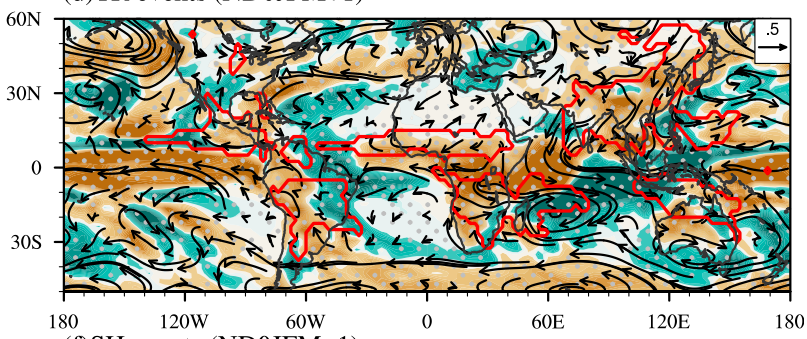

(f)SH events (ND0JFM+1)

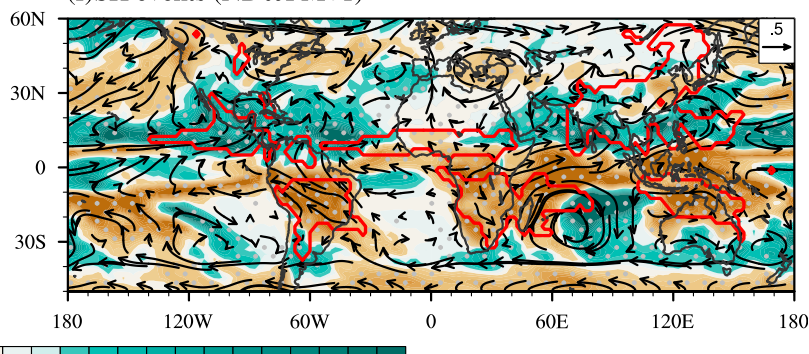

$\begin{array}{lllllllllllll}-1.1 & -0.9 & -0.7 & -0.5 & -0.3 & -0.1 & 0 & 0.1 & 0.3 & 0.5 & 0.7 & 0.9 & 1.1\end{array}$

FIG. 4. Precipitation (shading; $\mathrm{mm} \mathrm{day}^{-1}$ ) and 850 -hPa wind anomalies (vectors) in the first (left) boreal summer (MJJAS) and (right) boreal winter (NDJFM) following (a),(b) northern, (c),(d) tropical, and (e), (f) southern volcanic eruptions based on the CESM-LME simulation. The significance levels are determined according to the Monte Carlo test, and the values that are significant at the $90 \%$ confidence level are dotted. The red lines represent monsoon regions.

seen over Asian monsoon region following northern and tropical eruptions, while wetter conditions are evident following southern eruptions (Figs. $2 \mathrm{a}-\mathrm{c}$ ). The reconstructed precipitation over China further indicates that the monsoon precipitation over China decreased (increased) following northern (southern) eruptions (Figs. 2i-k). Similar results are obtained based on the proxy May-September Asian precipitation (Figs. 2e-g). The averaged PDSI/precipitation anomalies over the Asian monsoon region in three reconstructions show consistent dry condition following northern and tropical eruptions and wet condition after southern eruptions (Figs. 2d,h,l). Thus, the multiple sets of reconstructions reveal divergent hydrological responses following the three types of volcanic eruptions. There are some regional differences in mean responses and spread, which may be partly due to the different periods of reconstructions, the number of volcanoes, and the quality of the reconstructions (Table 3).

\section{b. Hydroclimate responses in instrumental data}

Instrumental data, which are shorter in the coverage of time period but generally have higher quality, also reveal results similar to those of the long-term proxy data. Some eruptions occur during or around El Niño years; after removing the ENSO influence, the observed $\mathrm{NH}(\mathrm{SH})$ monsoon precipitation decreased after northern (southern) eruptions, and increased following southern (northern) eruptions based on the GPCC dataset (Figs. 3a-f). To avoid the offset of ununiform positive and negative precipitation anomalies when taking the regional average, the percentage of anomalous wet (dry) grid cells relative to total monsoon regions [anomalous wet (dry) grid cells/all grid cells over monsoon regions] is regarded as the hydroclimate response to volcanic eruptions in the observation. We used six sets of instrumental precipitation data with higher resolution, observed standardized precipitation 

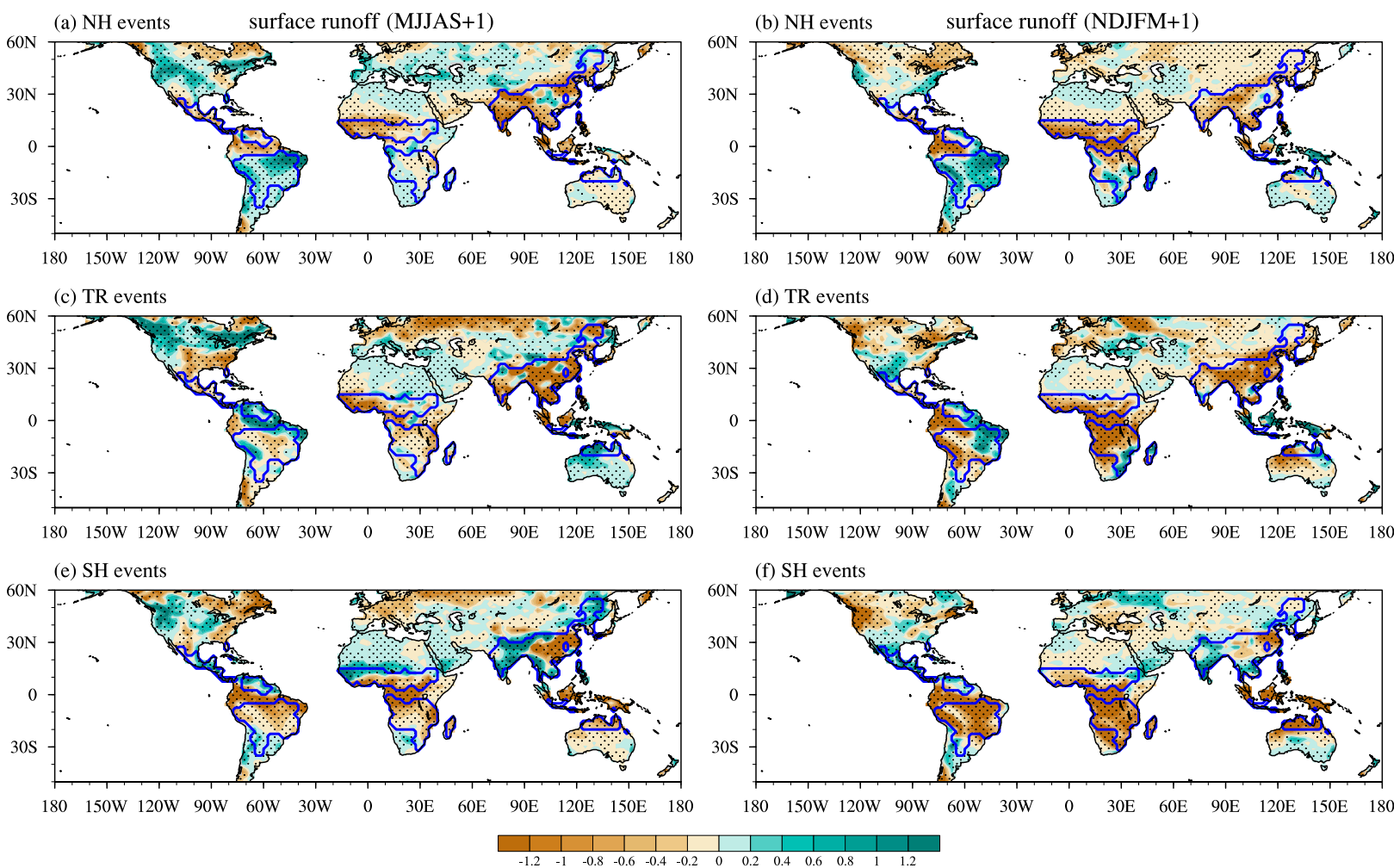

FIG. 5. Surface runoff $\left(\mathrm{mm} \mathrm{s}^{-1} \times 10^{6}\right)$ anomalies in the first (left) boreal summer (MJJAS) and (right) boreal winter (NDJFM) following (a),(b) northern, (c),(d) tropical, and (e),(f) southern volcanic eruptions based on the CESM-LME simulation. The significance levels are determined according to the Monte Carlo test, and the values that are significant at the $90 \%$ confidence level are dotted. The blue lines represent monsoon regions.

evapotranspiration index calculated based on instrumental meteorological elements to reveal drier/ wetter conditions over monsoon regions after volcanic eruptions. Percentage greater than $50 \%$ represents more than one-half of the region is getting wetter/drier. Specifically, we calculate the dry grid percentage over $\mathrm{NH}$ (SH) monsoon regions after northern (southern) volcanic eruptions and tropical eruptions, and calculate the wet grid percentage over $\mathrm{NH}(\mathrm{SH})$ monsoon regions after southern (northern) volcanic eruptions. We note that more than half of the monsoon region in the Northern (Southern) Hemisphere features a decreased precipitation after northern (southern) and tropical volcanic eruptions. About 53\% of the monsoon regions in the Northern (Southern) Hemisphere exhibit an increased precipitation following southern (northern) volcanic eruptions (supplemental Fig. S4). To conclude, the results based on observational datasets also suggest similar conclusion to that based on reconstructions.

The above results suggest that the $\mathrm{NH}(\mathrm{SH})$ monsoon precipitation is weakened by the northern (southern) and tropical eruptions, and is enhanced by the southern (northern) eruptions.

\section{c. Hydroclimate response in CESM-LME simulation}

The divergent responses to three types of volcanic eruptions revealed by proxy and instrumental data are further demonstrated by model simulations. To analyze the hydroclimate response in monsoon regions to different eruptions, we use the volcanic-only forcing experiment in CESM-LME to examine the mean precipitation, extreme precipitation, surface runoff and NPP responses for the past millennium. The precipitation and $850-\mathrm{hPa}$ wind anomalies in the first boreal summer and boreal winter following northern, tropical, and southern volcanic eruptions based on the CESM-LME simulation are shown in Fig. 4. We found that the simulated precipitation response is consistent with the results derived from proxy/instrumental data (Fig. 4). We averaged the response in each submonsoon region and found wetter conditions over $\mathrm{SH}$ submonsoon regions and an opposite signal over the Northern Hemisphere after northern eruptions (see Fig. 8 below for regional average). Following tropical eruptions, the precipitation anomalies are characterized by the tendency for wet regions to become drier 

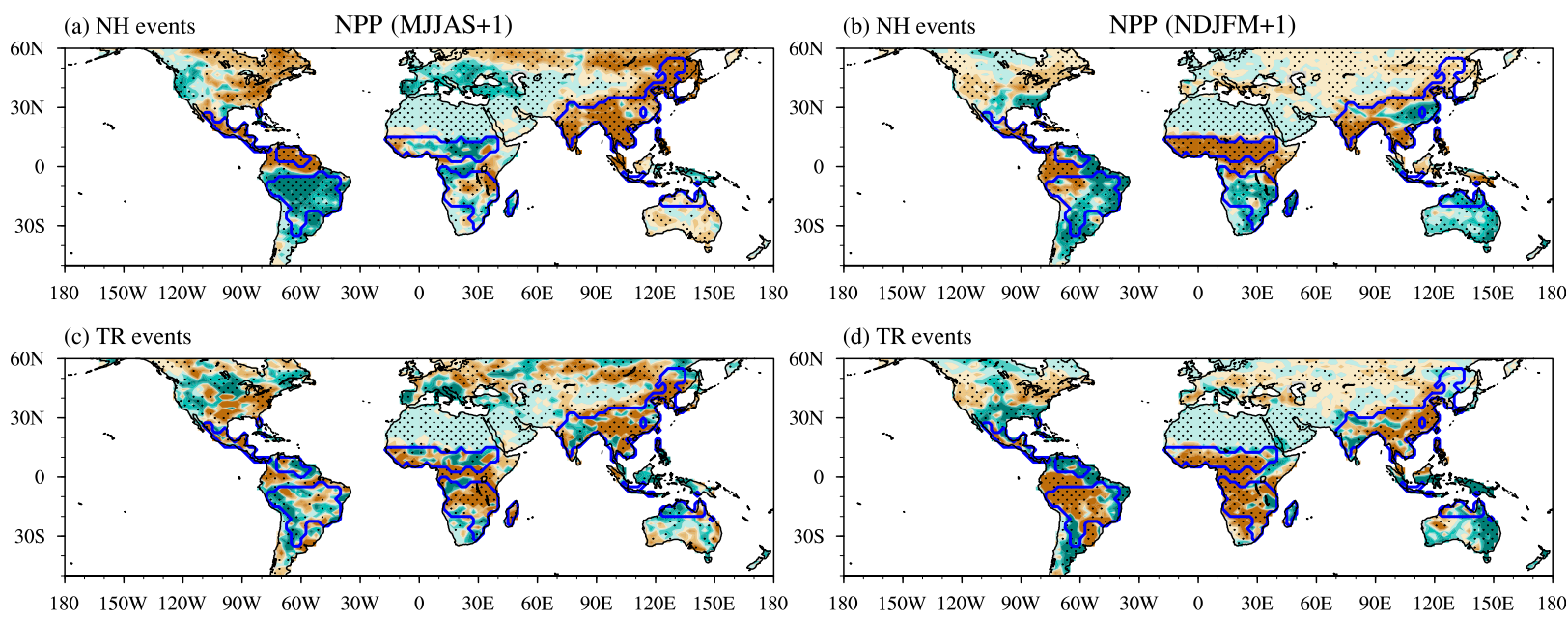

(d) TR events

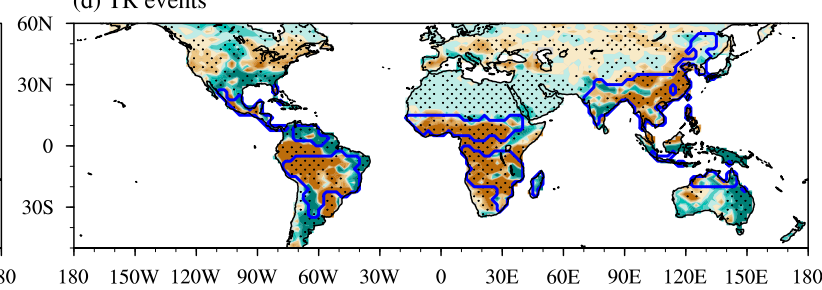

(e) $\mathrm{SH}$ events
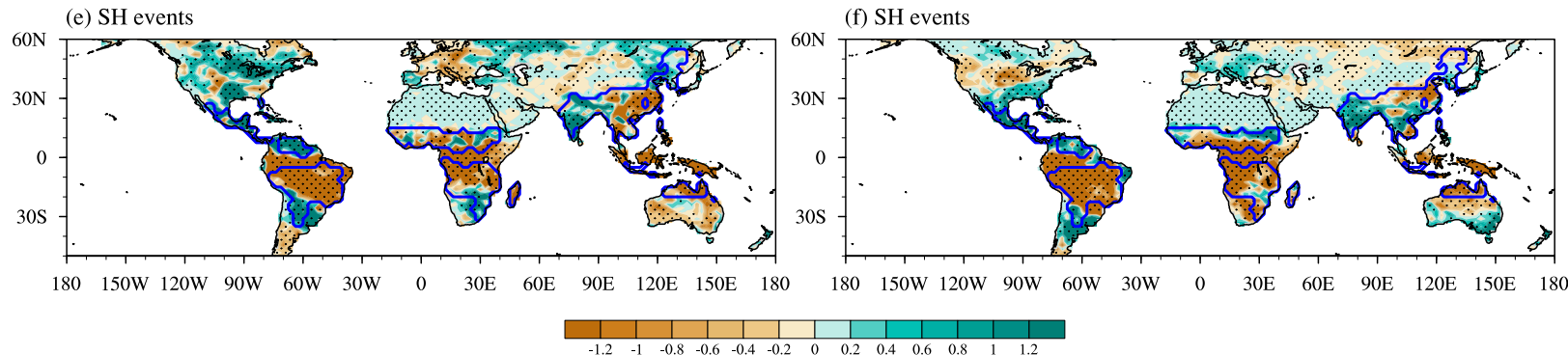

FIG. 6. As in Fig. 5, but for the response of net primary production $\left(\mathrm{gC} \mathrm{m}^{-2} \mathrm{~s}^{-1} \times 10^{6}\right)$.

(Figs. 4c,d). Following southern eruptions, drying is observed over the $\mathrm{SH}$ submonsoon regions and wetting over the Northern Hemisphere (Figs. 4e,f).

We further extend our analysis to runoff and NPP. The responses of surface runoff and NPP show similar results with precipitation (Figs. 5 and 6). The averaged surface runoff and NPP anomalies over submonsoon regions reveal a significant dry conditions over $\mathrm{NH}$ (SH) and global monsoon regions following northern (southern) eruptions and tropical eruptions, respectively. An obvious wet anomaly over SH (NH) monsoon regions is observed after northern (southern) eruptions (see Figs. 8a-c for regional average). From a quantitative perspective, the changes are expressed as a percentage of the climatological hydroclimate factors (Figs. 8d-f). The response of surface runoff and NPP is stronger than that of precipitation over some submonsoon regions such as the South African monsoon region after northern and tropical eruptions, which suggests that the volcanic eruptions cause significant changes in water resources and ecosystems. The hydroclimate response to northern and southern eruptions is more pronounced than the response to tropical eruptions. Monsoon precipitation in one hemisphere is reduced by approximately $8 \%-11 \%$
[NH monsoon precipitation is decreased by $8 \%(6 \%-$ $10 \%$ ) after northern eruptions; $\mathrm{SH}$ monsoon precipitation is decreased by $11 \%(6 \%-17 \%)$ after southern eruptions] after volcanic forcing occurs in the same hemisphere, and is increased by approximately $1.2 \%-$ $3 \%$ [ $\mathrm{NH}$ monsoon precipitation is increased by $1.2 \%$ (from $-3 \%$ to $3 \%$ ) after southern eruptions; $\mathrm{SH}$ monsoon precipitation is increased by $3 \%$ (from $-1 \%$ to $6 \%$ ) after northern eruptions] after eruptions occur in the other hemisphere. The increased precipitation is much smaller that the decreased precipitation since the positive contribution of dynamic effect is offset by the negative contribution of thermodynamic effect.

Model simulation helps us to extend the analysis from mean state precipitation to extreme factors. The extreme precipitation also reveals a similar response to mean precipitation (Fig. 7). We select two extreme precipitation indices to represent the extreme factors related to hydroclimate response. One is consecutive dry days (CDD), which is the maximum number of consecutive days with precipitation less than $1 \mathrm{~mm}$, and the other is consecutive wet days (CWD), which is the maximum number of consecutive days with precipitation larger than $1 \mathrm{~mm}$. The decrease of CWD and 
(a) NH events

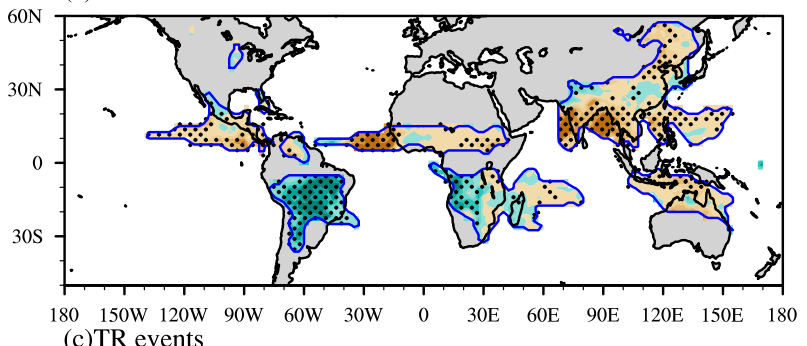
(c)TR events

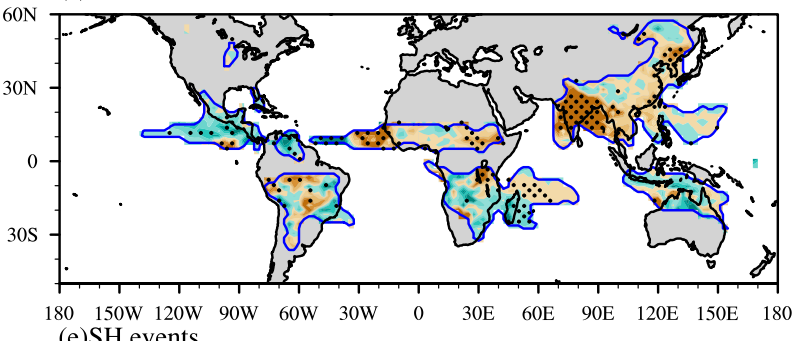
(e)SH events

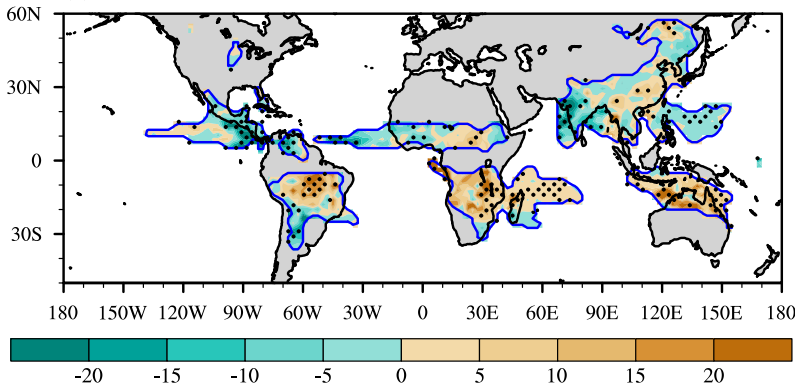

(b)NH events

CWD (yr+1)

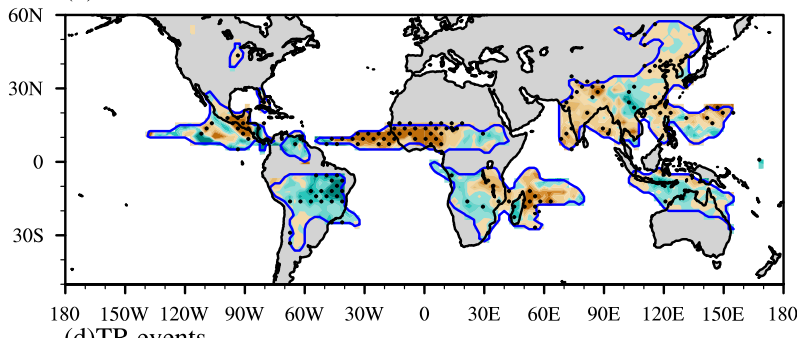

(d)TR events

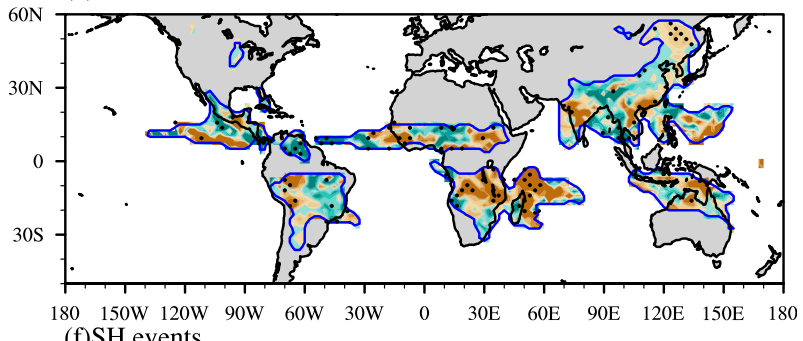

$180 \quad 150 \mathrm{~W} 120 \mathrm{~W}$
(f)SH events

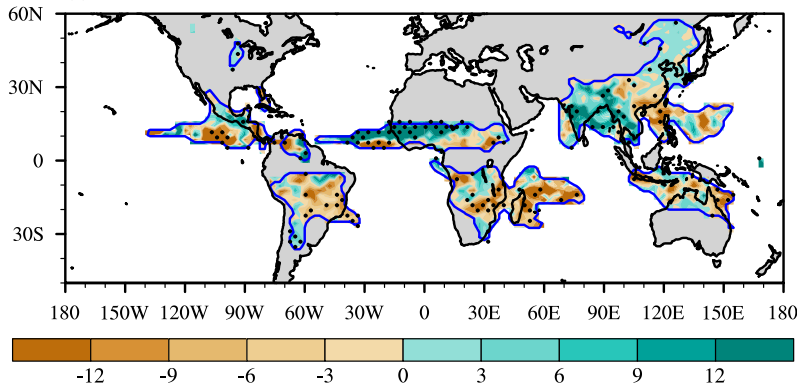

FIG. 7. (left) Consecutive dry days and (right) consecutive wet days anomalies following (a),(b) northern, (c),(d) tropical, and (e),(f) southern volcanic eruptions. The significance levels are determined according to a Student's $t$ test, and the values that are significant at the $90 \%$ confidence level are dotted. Note that the color scale for CDD response is reversed, with brown indicating an increase of CDD, which represents dry conditions. The blue lines represent monsoon regions.

increase of CDD denote dry conditions and vice versa. Both CWD and CDD show the same signal as the mean precipitation after volcanic eruptions (Fig. 7), which means that volcanic eruptions not only affect average precipitation, but also cause corresponding changes in extreme precipitation, which are related to drought and flood hazards.

The averaged extreme precipitation responses over submonsoon regions are compared in Fig. 8; it is evident that the response of extreme precipitation and mean precipitation is consistent in most of the submonsoon regions. In general, the extreme precipitation response agrees with the changes in hydroclimate after different volcanic eruptions, among which the changes in CDD over monsoon regions are the most significant, exceeding $12 \%(8 \%-17 \%)$ in $\mathrm{NH}$ monsoon regions after northern eruptions (Figs. 8d-f).

We further evaluate the ensemble spread; the spread among the ensemble members is shown in Fig. 8 (dashed black bars). There are large uncertainties among different members over the Australian monsoon regions, which may originate from small land monsoon area since the signal-to-noise ratio depends on the region size. Generally, the precipitation response to northern eruptions is consistent among different members, but the response over $\mathrm{SH}(\mathrm{NH})$ monsoon region after tropical (southern) eruptions shows a large spread between different members, which demonstrates that internal variability also plays an important role.

\section{d. Physical mechanism behind the precipitation response: Dynamic processes}

To understand the mechanisms of changes in precipitation over global monsoon regions following volcanic eruptions, we use a method of moisture budget analysis (Chou et al. 2009) and MSE budget (Neelin and Held 1987). 
(a) $\mathrm{NH}$ events

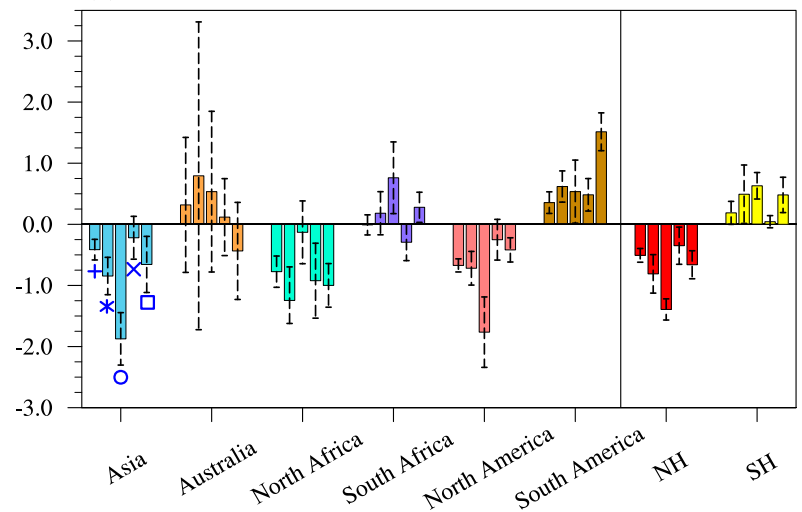

(b) TR events

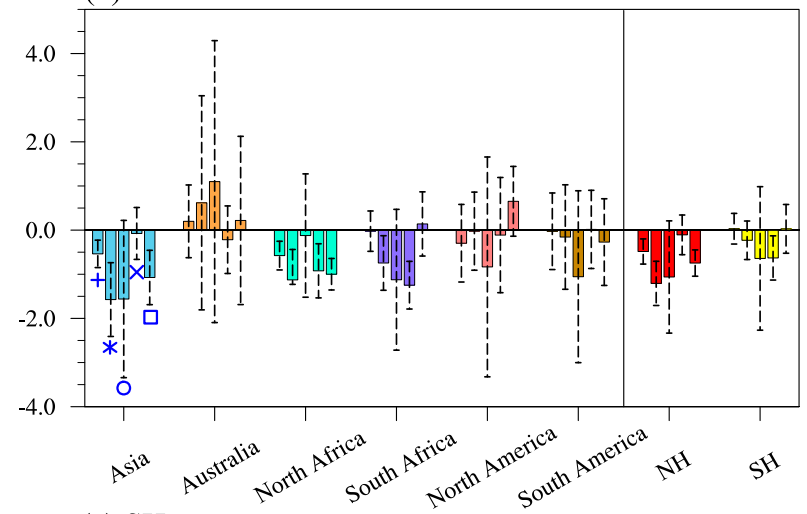

(c) $\mathrm{SH}$ events

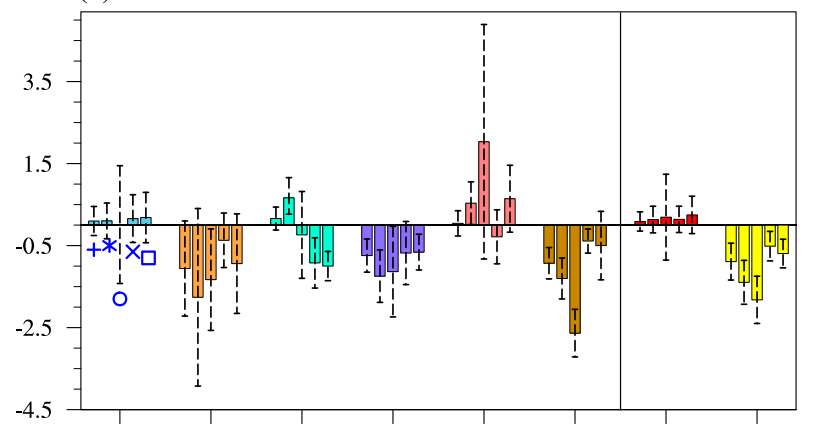

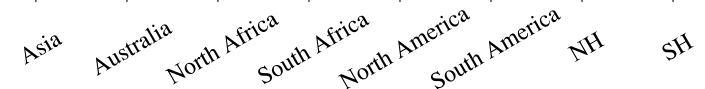

+ precipitation $*$ surface runoff $\bigcirc$ net primary production $\times \quad \mathrm{CWD}^{*}\left(10^{-1}\right) \quad \square \quad \mathrm{CDD}\left({ }^{*}-10^{-1}\right)$ (d) NH events (percentage)

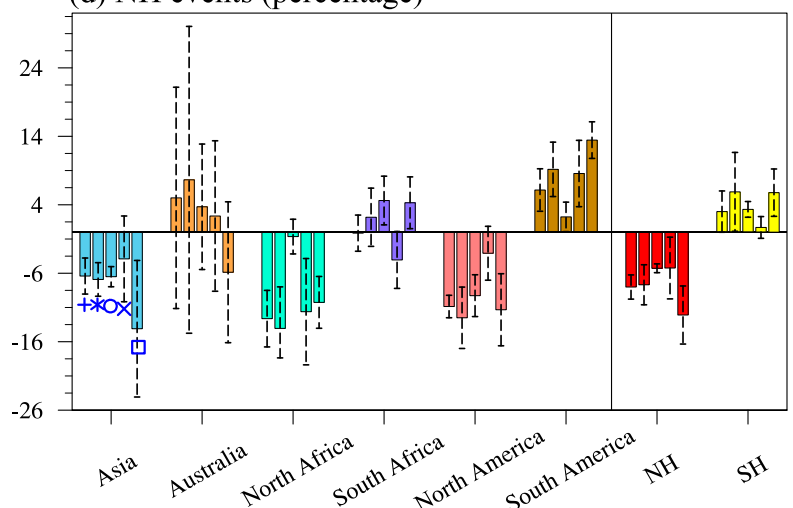

(e) TR events (percentage)

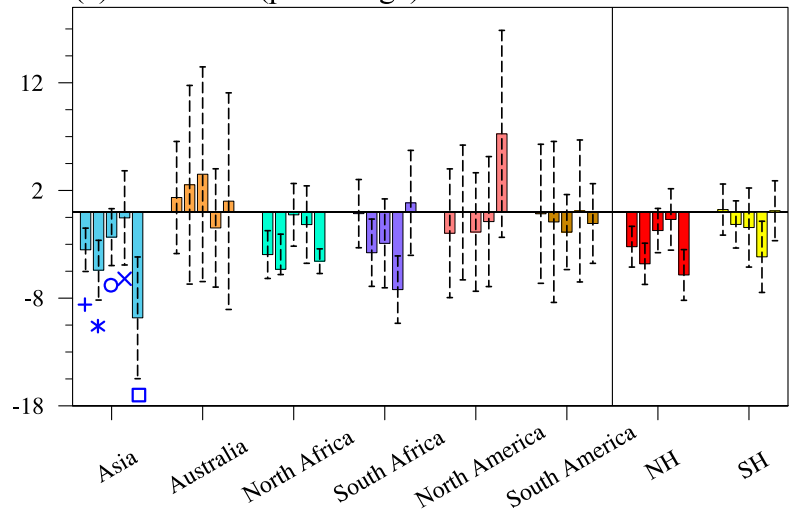

(f) $\mathrm{SH}$ events (percentage)

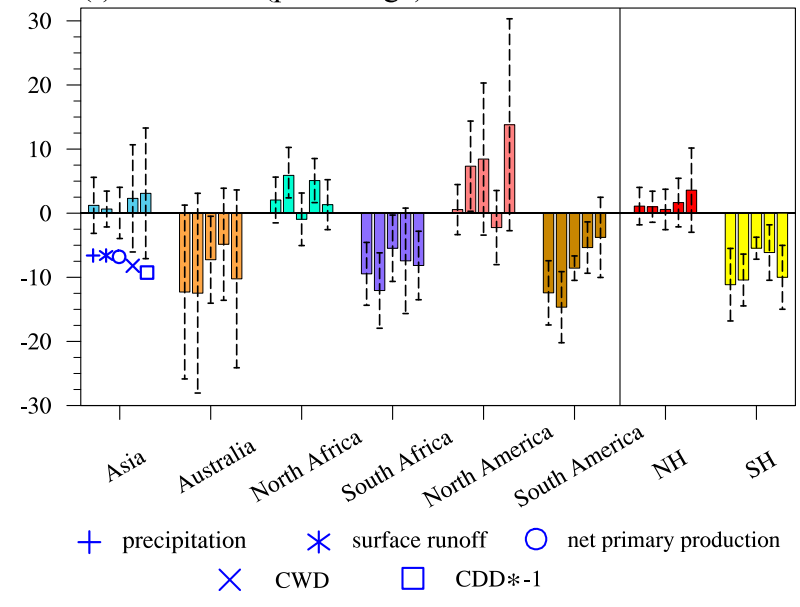

\section{$\square$ Asia $\square$ Australia $\square$ North Africa $\square$ South Africa}

$\square$ North America $\square$ South America $\square \mathrm{NH} \square \mathrm{SH}$

FIG. 8. Local summer precipitation $\left(\mathrm{mm} \mathrm{day}^{-1}\right)$, surface runoff $\left(\mathrm{mm} \mathrm{s}^{-1} \times 10^{6}\right)$, net primary production $\left(\mathrm{gC} \mathrm{m}^{-2} \mathrm{~s}^{-1} \times 10^{6}\right)$, and extreme precipitation response in the form of annual CWD (days $\times 10^{-1}$ ) and CDD (days $\left.\times-10^{-1}\right)($ left) anomalies and (right) responses expressed as percent of the climatological hydroclimate factors (\%) averaged over submonsoon regions following (a),(d) northern eruptions, (b),(e) tropical eruptions, and (c),(f) southern eruptions. The dashed black bars represent the spread among five members in the model simulation (ranges of 1 standard deviation). The blue symbols represent different variables. 
$\mathrm{NH}$ monsoon region budget (NH events)

(a) Moisture budget

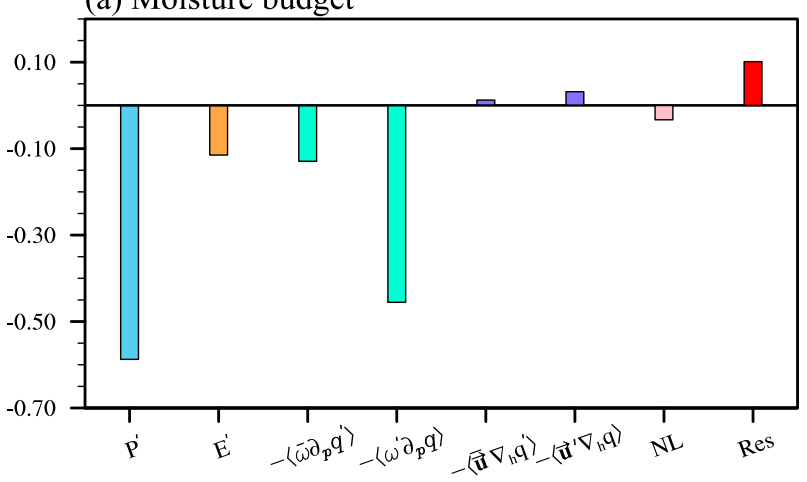

(b) MSE budget

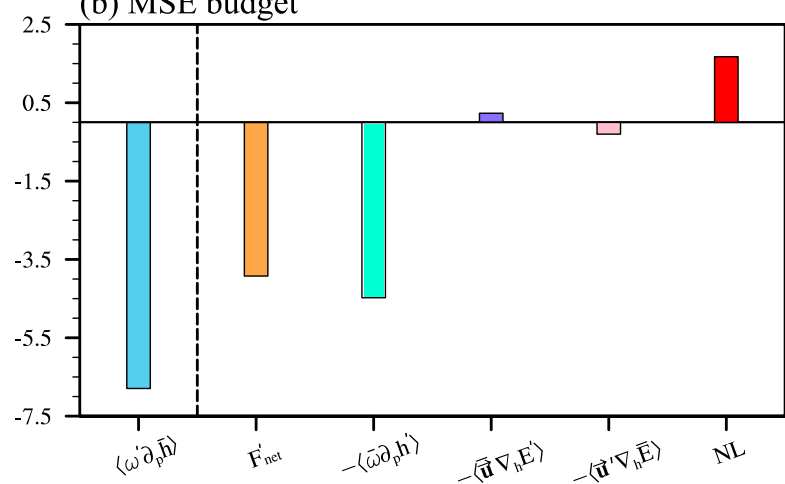

$\mathrm{SH}$ monsoon region budget ( $\mathrm{NH}$ events)

(c) Moisture budget

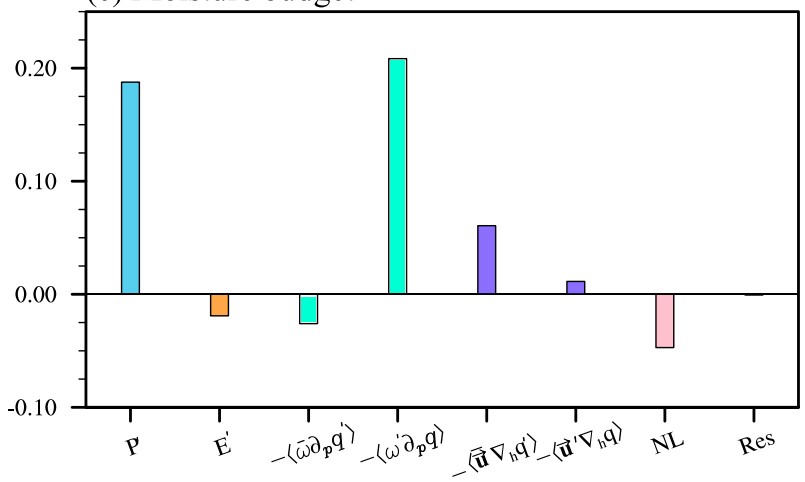

(d) MSE budget

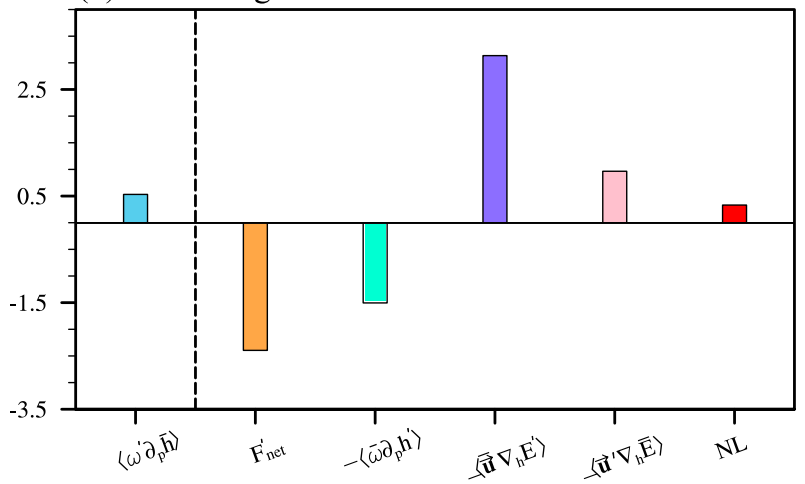

FIG. 9. (a),(c) Moisture budget and (b),(d) moist static energy budget for precipitation anomaly (mm day ${ }^{-1}$ ) responses over the (top) $\mathrm{NH}$ monsoon region following northern eruptions (the diagnosis of the SH monsoon region after southern eruptions has similar results) (bottom) SH monsoon region following northern eruptions (the diagnosis of the NH monsoon region after southern eruptions has similar results).

\section{1) DECREASED NH (SH) MONSOON PRECIPITATION INDUCED BY NORTHERN (SOUTHERN) VOLCANIC ERUPTIONS}

According to the moisture budget analysis, the negative anomalous advection of the climatological vertical moisture by descending anomalies $\left(-\left\langle\omega^{\prime} \partial_{p} \bar{q}\right\rangle\right)$ plays a dominant role in the negative precipitation over the $\mathrm{NH}(\mathrm{SH})$ monsoon regions after northern (southern) eruptions (Fig. 9a and supplemental Fig. S6a), while the horizontal moisture advection and the evaporation anomalies have relatively small contribution. In the monsoon regions, the vertical profile of $\omega^{\prime}$ shows a top-heavy bow structure with a maximum at approximately $500 \mathrm{hPa}$, and the vertical profile of climatological MSE $\bar{h}$ shows a bottom-heavy bow structure with a maximum at $700 \mathrm{hPa}$ (Fig. 10 and supplemental Fig. S5). Thus the vertical motions over the monsoon regions are constrained by the MSE budget balance. The positive value of vertical advections of climatological MSE $\left(-\left\langle\omega^{\prime} \partial_{p} \bar{h}\right\rangle\right)$ is primarily balanced by negative net energy flux anomalies $F_{\text {net }}^{\prime}$ and anomalous vertical MSE advection by climatological vertical motion $\left(-\left\langle\bar{\omega} \partial_{p} h^{\prime}\right\rangle\right)$ (Fig. 9b and supplemental Fig. S6b).

The term $F_{\text {net }}^{\prime}$ includes nine components, among which the net solar flux at the surface and latent heat flux play a dominant role (Figs. 11c-e and supplemental Figs. S7c-e). With the reduction in shortwave radiation following northern (southern) eruptions, the surface temperature and specific humidity decreases. Because of the differences in land and ocean heat capacity, the land-ocean thermal contrast decreases significantly [supplemental Fig. S9, consistent with Iles et al. (2013)], which, coupled with the decreased (increased) hemispherical thermal contrast induced by the different sulfate aerosol injections over $\mathrm{NH}(\mathrm{SH})$, results in a weakening of $\mathrm{NH}(\mathrm{SH})$ monsoon circulation (recall Figs. 4a and 4f shown before). The weakened wind speed and decreased specific humidity lead to the reduction of latent heat flux. The term $-\left\langle\bar{\omega} \partial_{p} h^{\prime}\right\rangle$ is related to the change in the gross 
(a) $\mathrm{NH}$ monsoon region

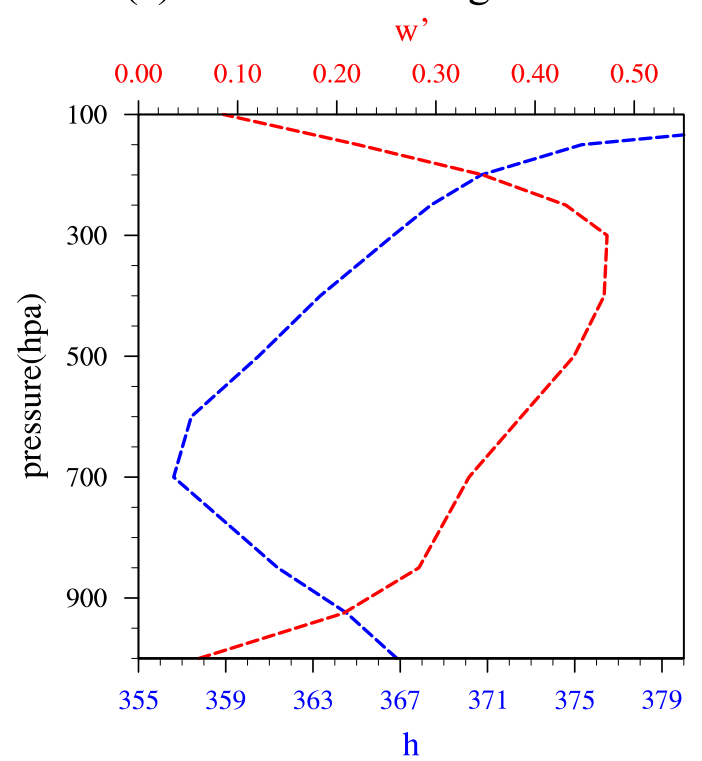

(b) SH monsoon region

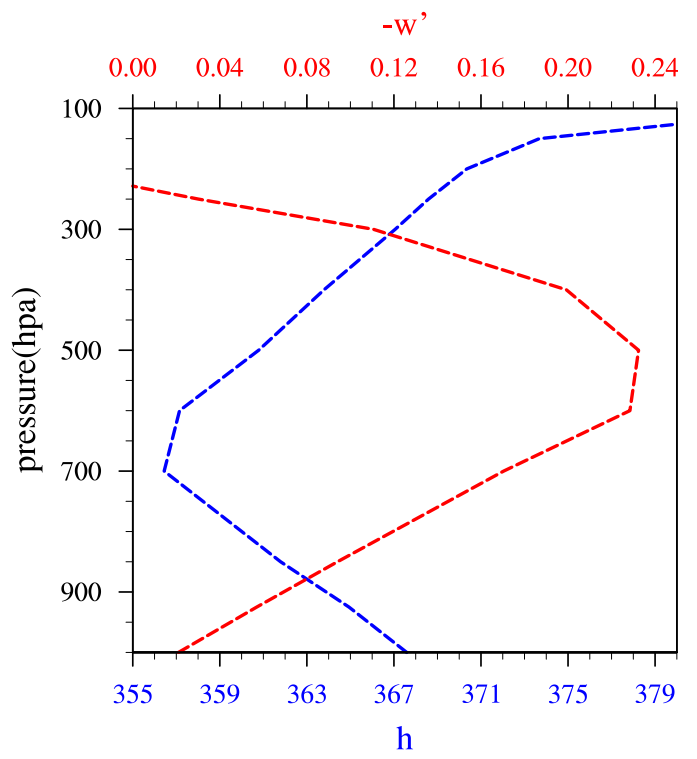

FIG. 10. Vertical profiles of anomalous omega in the first local summer after northern volcanic eruptions (red line; $10^{-2} \mathrm{~Pa} \mathrm{~s}^{-1}$ ) and the climatological MSE (blue line; $10^{3} \mathrm{~J} \mathrm{~kg}^{-1}$ ) averaged over the (a) $\mathrm{NH}$ and (b) SH monsoon regions.

moist stability caused by the vertical structure changes in the MSE $\left(h^{\prime}\right)$. Analysis of the vertical profiles of averaged $h^{\prime}$ and its subcomponents (dry static energy $s^{\prime}=$ $C_{p} T+\phi^{\prime}$ and latent energy $L_{v} q^{\prime}$ ) over monsoon regions finds that the vertical structure of $h^{\prime}$ is dominated by the $L_{v} q^{\prime}$ component (Fig. 12 and supplemental Fig. S8), which indicates an increase in gross moist stability $-\left\langle\bar{\omega} \partial_{p} h^{\prime}\right\rangle<0$ and tends to suppress local convection. (b) wdha

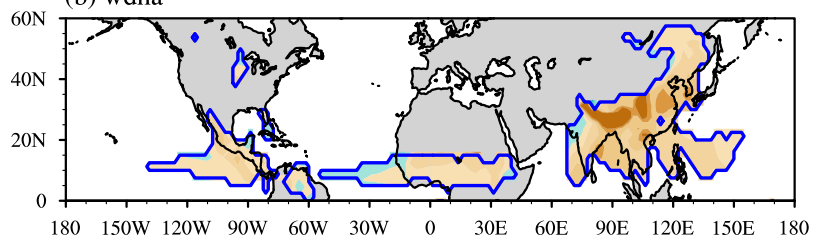

(d) fsnsa

(a) wadph

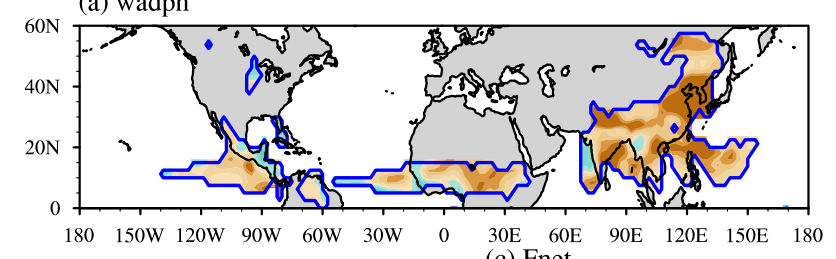

(c) Fnet

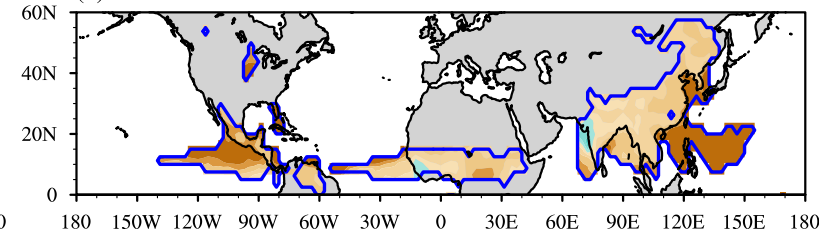

(e) lhflxa

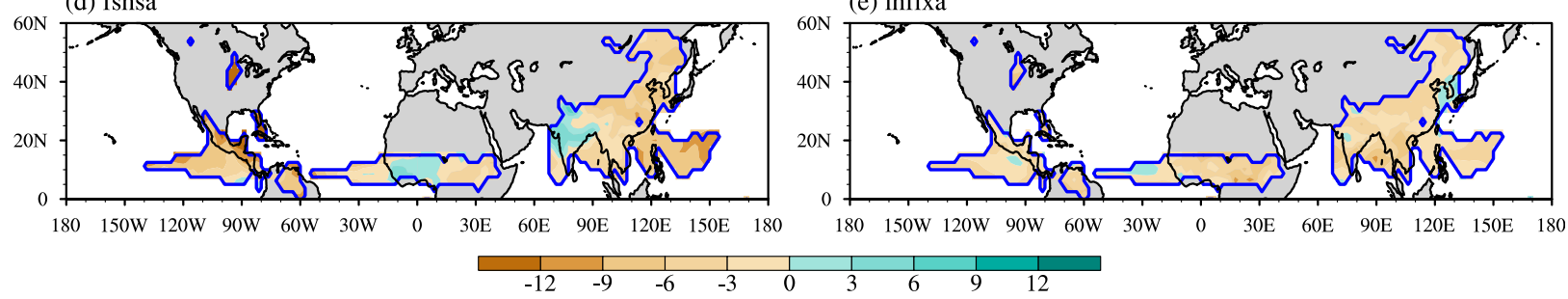

FIG. 11. The spatial distribution of each term of the MSE budget analysis over the $\mathrm{NH}$ monsoon region following northern eruptions $\left(\mathrm{W} \mathrm{m}^{-2}\right)$ :

(a) anomalous vertical advections of climatological MSE $\left(\left\langle\omega^{\prime} \partial_{p} \bar{h}\right\rangle\right)$, (b) anomalous vertical MSE advection by climatological vertical motion $\left(-\left\langle\bar{\omega} \partial_{p} h^{\prime}\right\rangle\right)$, (c) net energy flux anomalies $F_{\text {net }}^{\prime}$, (d) net surface short wave flux anomalies $\left(S_{s}^{\downarrow}-S_{s}^{\uparrow}\right)^{\prime}$, and (e) latent heat flux anomalies $\left(\mathrm{LH}^{\prime}\right)$. 


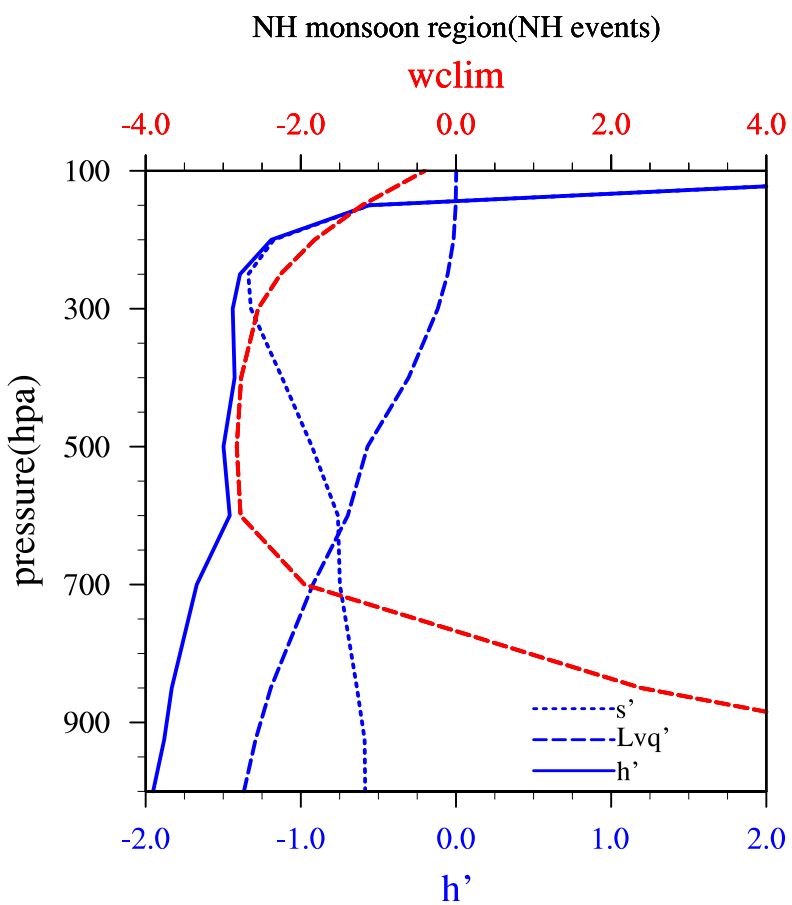

FIG. 12. Vertical profiles of climatological omega (red line; $10^{-2} \mathrm{~Pa} \mathrm{~s}^{-1}$ ) and anomalous MSE (blue solid line), dry static energy $\left(s^{\prime}=C_{p} T^{\prime}+\phi^{\prime}\right.$; blue dotted line $)$, and latent energy $\left(L_{v} q^{\prime}\right.$; blue dashed line) $\left(10^{3} \mathrm{~J} \mathrm{~kg}^{-1}\right)$ averaged over the $\mathrm{NH}$ monsoon region following northern eruptions.

\section{2) INCREASED NH (SH) MONSOON PRECIPITATION INDUCED BY SOUTHERN (NORTHERN) VOLCANIC ERUPTIONS}

The increased NH (SH) monsoon precipitation following southern (northern) eruptions is caused by the positive anomalous advection of climatological vertical moisture by ascending anomalies $\left(-\left\langle\omega^{\prime} \partial_{p} \bar{q}\right\rangle\right)$ (Fig. 9c and supplemental Fig. S6c). The MSE budget analysis reveals that the net energy flux anomalies $F_{\text {net }}^{\prime}$ and anomalous vertical MSE advection by climatological vertical motion $\left(-\left\langle\bar{\omega} \partial_{p} h^{\prime}\right\rangle\right)$ play a negative role. The vertical advection of climatological MSE $\left(-\left\langle\omega^{\prime} \partial_{p} \bar{h}\right\rangle\right)$ is primarily balanced by the horizontal advection of anomalous moist enthalpy by climatological wind $\left[-\left\langle\overline{\mathbf{u}} \cdot \nabla_{h}\left(C_{p} T+L_{v} q\right)^{\prime}\right\rangle\right]$ and horizontal advection of climatological moist enthalpy by anomalous wind $\left[-\left\langle\mathbf{u}^{\prime} \cdot \nabla_{h} \overline{\left(C_{p} T+L_{v} q\right)}\right\rangle\right]$ (Fig. 9d and online supplemental Fig. S6d). Both moisture advection and temperature advection contribute to $-\left\langle\overline{\mathbf{u}} \cdot \nabla_{h}\left(C_{p} T+L v q\right)^{\prime}\right\rangle$ and $-\left\langle\mathbf{u}^{\prime} \cdot \nabla_{h} \overline{\left(C_{p} T+L_{v} q\right)}\right\rangle$. The anomalous temperature (specific humidity) exhibits a positive zonal gradient in the $\mathrm{SH}$ monsoon regions; thus, the climatological easterly wind component advects wet (high moist enthalpy) air into the SH monsoon regions (supplemental
Figs. S10a,b). The climatological temperature (specific humidity) has a positive meridional gradient in the $\mathrm{SH}$ monsoon regions, so the anomalous northerly wind component associated with strengthened cross-equator flow advects wet (high moist enthalpy) air into the $\mathrm{SH}$ monsoon regions (Fig. 13 and supplemental Figs. S10c,d). These two factors strengthen the upward motion and precipitation over $\mathrm{SH}$ monsoon regions.

\section{Summary and concluding remarks}

While there are increasing evidences showing that the volcanic aerosol has significant impact on global precipitation change, the latitude dependence of volcanic eruptions' impacts on precipitation over global monsoon regions in the last millennium is not well understood. In this study, the hydroclimate responses to volcanic eruptions at different latitudes over global monsoon regions are investigated by combining proxy data, instrumental data, and climate model simulations. The analysis extends from mean state precipitation changes to the surface runoff, net primary production and extreme precipitation. About 10 sets of hydroclimate reconstruction over global monsoon regions and instrumental data with high resolution and long time scale are collected and used to reveal the hydroclimate responses. The last millennial climate ensemble simulations CESM-LME are further used to reveal the underlying physical mechanisms. The schematic diagram of different volcanic eruption induced hydroclimate responses is depicted in Fig. 14. The major findings are summarized below:

1) Based on large sets of hydroclimate reconstructions that cover from the past few centuries to a thousand years, we find that monsoon precipitation in one hemisphere is enhanced (reduced) by the volcanic forcing occurring in the other (same) hemisphere. The results are further supported by instrumental data that cover a shorter time period but with higher spatial coverage (see precipitation responses depicted in Figs. 14a-c).

2) The findings of divergent hydroclimate responses based on reconstructions and instrumental data are further confirmed by using the CESM-LME simulation. The model responses are consistent with the proxy/instrumental data.

3) The underlying physical mechanisms are investigated by using quantitative diagnostic methods based on the CESM-LME simulations. We find that the dynamic processes related to changes in atmospheric circulation play a dominant role in precipitation responses. The results show that the volcanic eruptions 
(a) $\mathrm{NH}$ events Anomalous meridional wind

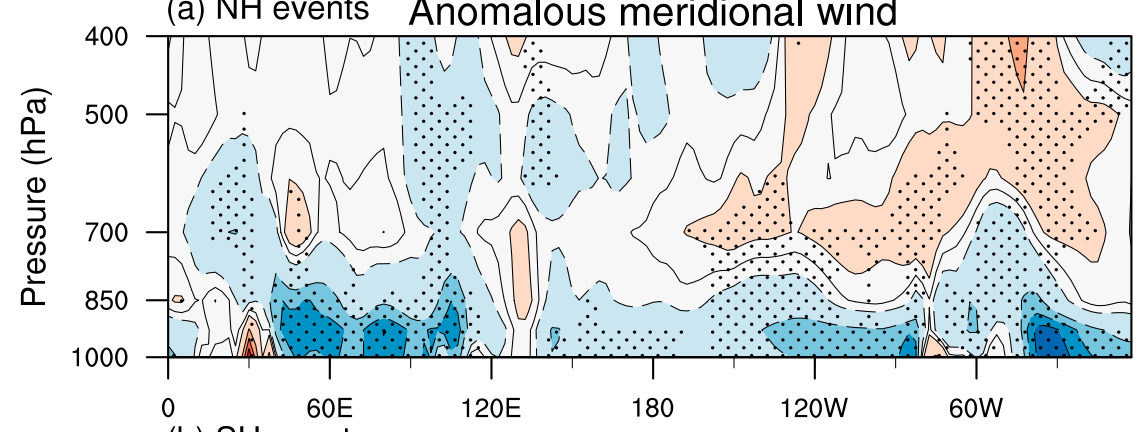

(b) SH events

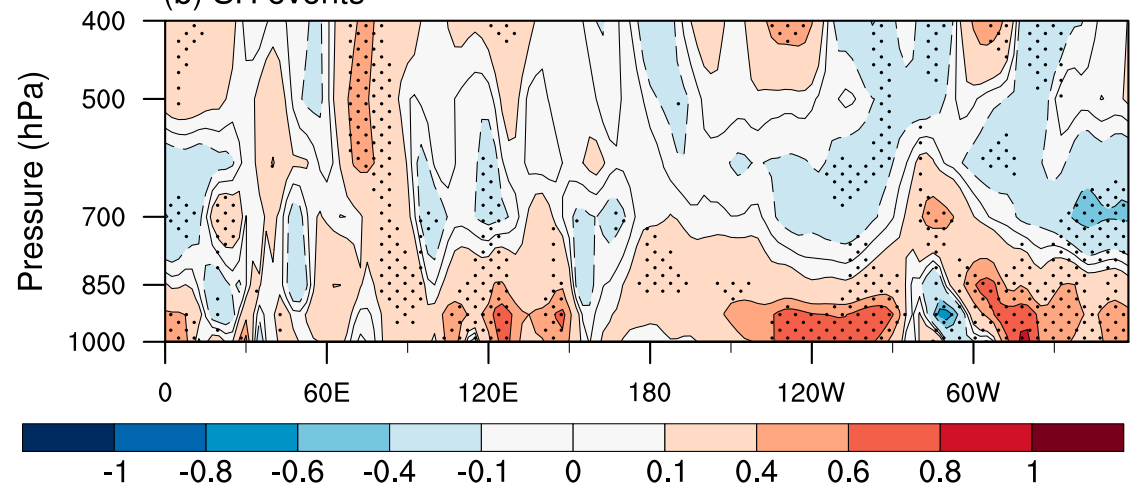

FIG. 13. Longitude-height cross section of the meridional wind $\left(\mathrm{m} \mathrm{s}^{-1}\right)$ anomalies averaged between $2.5^{\circ} \mathrm{S}$ and $2.5^{\circ} \mathrm{N}$ following (a) northern and (b) southern eruptions. The significance levels are determined according to the Monte Carlo test, and the values that are significant at the $90 \%$ confidence level are dotted.

in the Northern (Southern) Hemisphere will cause dry condition over the $\mathrm{NH}(\mathrm{SH})$ monsoon regions, mainly through the weakened monsoon circulation caused by decreased land-ocean thermal contrast, weakened cross-equator flow induced by decreased (increased) hemispherical thermal contrast, and weakened Walker circulation (Fig. 14 and supplemental Fig. S11) resulting from El Niño-like SST anomalies (Figs. 14a,c). The wet conditions over $\mathrm{NH}(\mathrm{SH})$ monsoon regions after southern (northern) eruptions are caused by increased (decreased) hemispherical thermal contrast and decreased landocean thermal contrast (Figs. 14a,c). For tropical eruptions, the reduction in monsoon precipitation is a result of a decreased land-ocean thermal contrast and an anomalous warming in the eastern $\mathrm{Pa}$ cific (Fig. 14b).

4) We extend our model simulation analysis from mean state precipitation to extreme precipitation. We highlight that the response of extreme precipitation to volcanic eruptions is consistent with that of average precipitation, but is more sensitive over monsoon regions, which is related to drought and flood hazards. Our study also provides new insights for a better understanding of volcanic impacts on surface runoff and NPP changes; the response of surface runoff and NPP is stronger than that of precipitation over some submonsoon regions, which means the eruptions will cause significant changes in water resources and ecosystems.

Our results imply that future volcanic eruptions located in different latitudes will impact the hydroclimate over global monsoon regions differently. It is thus imperative to consider the potential eruption of volcanoes at different hemispheres in the design of near-term decadal climate prediction experiments such as the Decadal Climate Prediction (DCPP) for phase 6 of the Coupled Model Intercomparison Project (CMIP6) (Boer et al. 2016). In addition, our results also have important implications for geoengineering based on solar radiation management. The hydroclimate responses over global monsoon regions need to be considered in the design or even potential implementation of geoengineering activities. We also acknowledge the model dependence of the results presented here. Both the external forcing data and model performance may impact the results. To understand the sources of 
(a) NH events

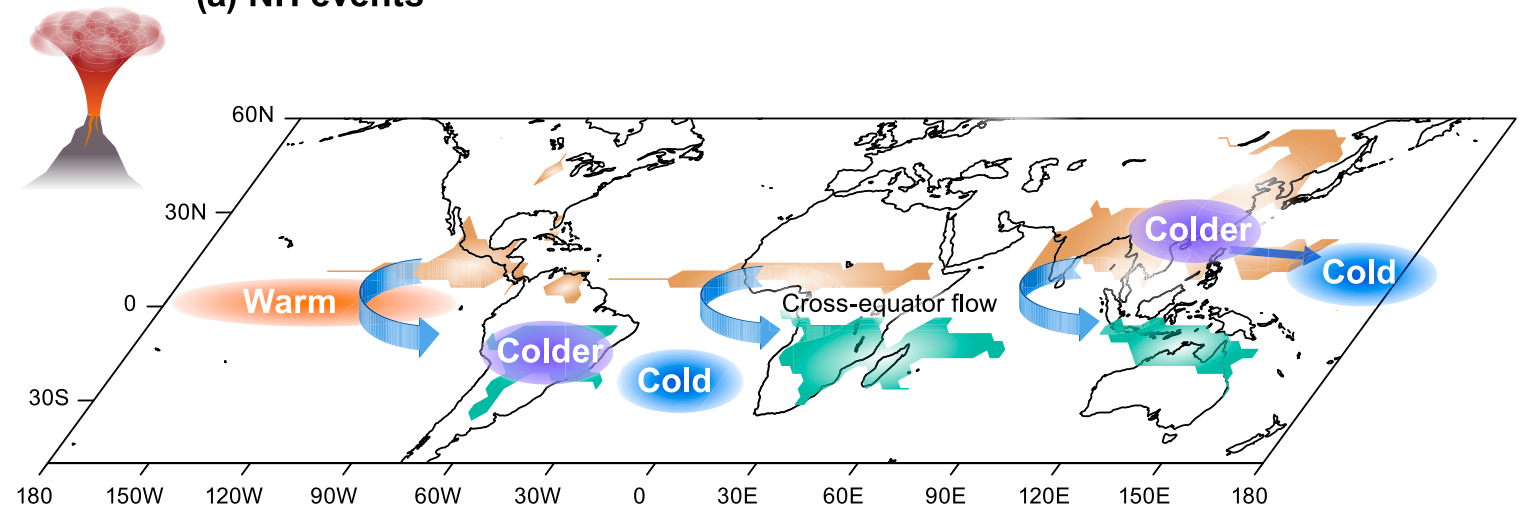

(b) TR events

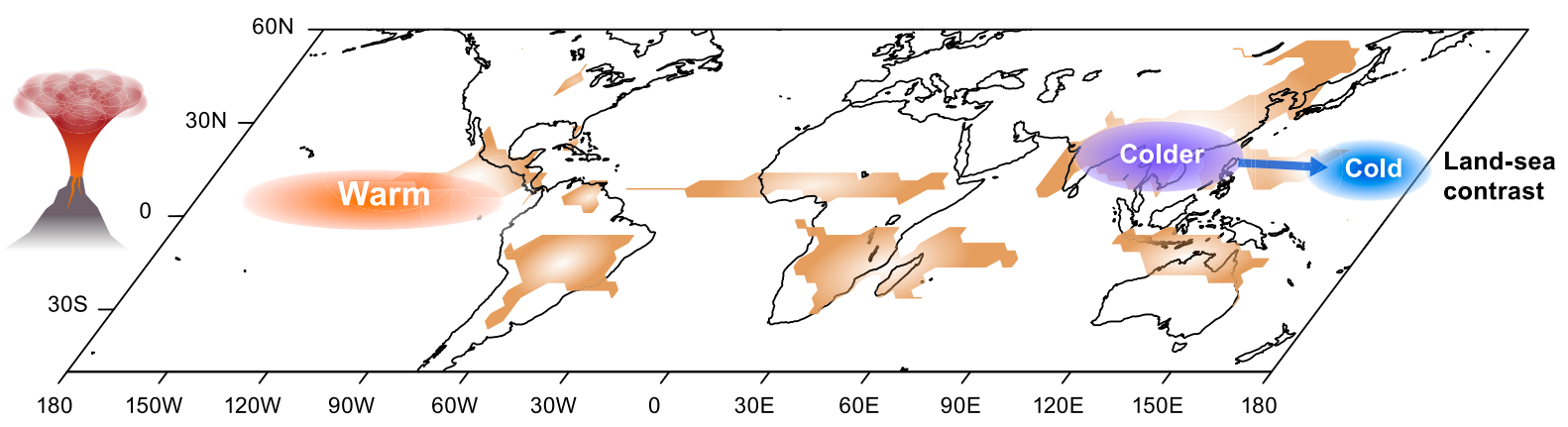

(c) SH events

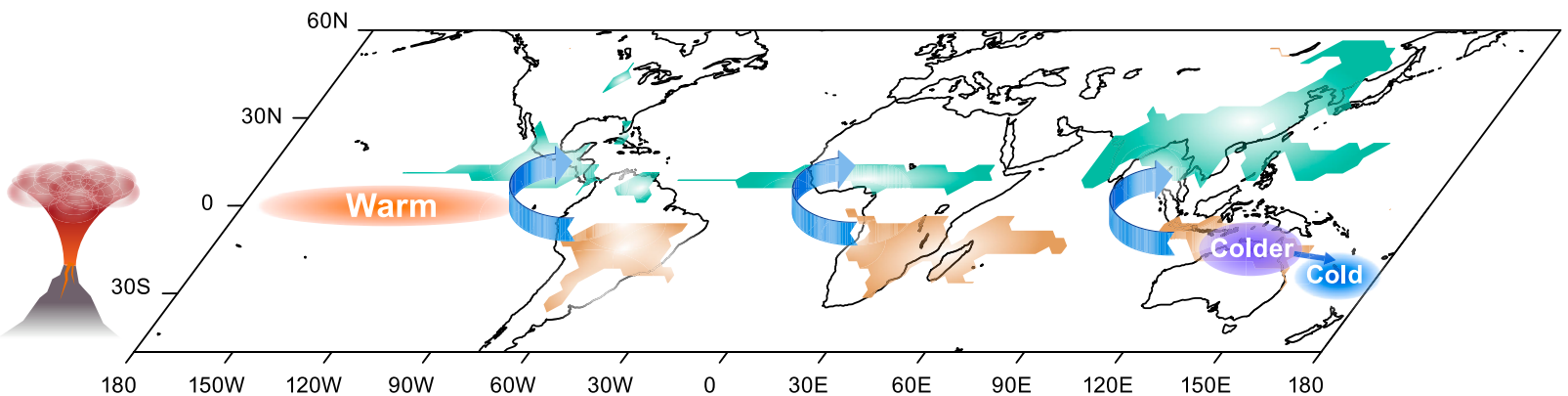

FIG. 14. Schematic diagram of different volcanic eruption-induced hydroclimate responses: (a) precipitation and low-level wind anomaly (vector) over monsoon regions in the first local summer after (a) northern, (b) tropical, and (c) southern eruptions. Positive and negative precipitation anomalies are denoted by green and brown, respectively. The orange ellipses denote the eastern Pacific warming. The purple and blue ellipses denote the surface cooling over the land and ocean, respectively.

uncertainties, the Model Intercomparison Project on the Climatic Response to Volcanic Forcing (VolMIP) has defined a coordinated set of idealized volcanic perturbation experiments to be carried out in alignment with the CMIP6 protocol (Zanchettin et al. 2016). VolMIP provides a common volcanic forcing dataset for each experiment to minimize differences in the applied volcanic forcing. The global monsoon responses to different volcanic forcing and the physical processes will be examined using the VolMIP experiments in future studies.

Acknowledgments. This work is jointly supported by the Strategic Priority Research Program of the Chinese 
Academy of Sciences (Grant XDA20060102), the International Partnership Program of the Chinese Academy of Sciences (Grant 134111KYSB20160031), and the National Natural Science Foundation of China (Grants 41330423 and 41675802). We also acknowledge support from the Jiangsu Collaborative Innovation Center for Climate Change and the U.K.-China Research and Innovation Partnership Fund through the Met Office Climate Science for Service Partnership (CSSP) China as part of the Newton Fund.

\section{REFERENCES}

Adams, J. B., M. E. Mann, and C. M. Ammann, 2003: Proxy evidence for an El Niño-like response to volcanic forcing. Nature, 426, 274-278, https://doi.org/10.1038/nature02101.

Anchukaitis, K. J., B. M. Buckley, E. R. Cook, B. I. Cook, R. D. D'Arrigo, and C. M. Ammann, 2010: Influence of volcanic eruptions on the climate of the Asian monsoon region. Geophys. Res. Lett., 37, L22703, https://doi.org/10.1029/2010GL044843.

Back, L. E., and C. S. Bretherton, 2009: A simple model of climatological rainfall and vertical motion patterns over the tropical oceans. J. Climate, 22, 6477-6497, https://doi.org/ 10.1175/2009JCLI2393.1.

Boer, G. J., and Coauthors, 2016: The Decadal Climate Prediction Project (DCPP) contribution to CMIP6. Geosci. Model Dev., 9, 3751-3777, https://doi.org/10.5194/gmd-9-3751-2016.

Chou, C., J. D. Neelin, C.-A. Chen, and J.-Y. Tu, 2009: Evaluating the "rich-get-richer" mechanism in tropical precipitation change under global warming. J. Climate, 22, 1982-2005, https://doi.org/10.1175/2008JCLI2471.1.

Colose, C. M., A. N. LeGrande, and M. Vuille, 2016: The influence of volcanic eruptions on the climate of tropical South America during the last millennium in an isotope-enabled general circulation model. Climate Past, 12, 961-979, https://doi.org/ 10.5194/cp-12-961-2016.

Cook, E. R., K. J. Anchukaitis, B. M. Buckley, R. D. D'Arrigo, G. C. Jacoby, and W. E. Wright, 2010: Asian monsoon failure and megadrought during the last millennium. Science, 328, 486-489, https://doi.org/10.1126/science.1185188.

D'Arrigo, R., R. Wilson, and A. Tudhope, 2009: The impact of volcanic forcing on tropical temperatures during the past four centuries. Nat. Geosci., 2, 51-56, https://doi.org/10.1038/ngeo393.

Dogar, M. M., G. Stenchikov, S. Osipov, B. Wyman, and M. Zhao, 2017: Sensitivity of the regional climate in the Middle East and North Africa to volcanic perturbations. J. Geophys. Res. Atmos., 122, 7922-7948, https://doi.org/10.1002/2017JD026783.

Feng, S., Q. Hu, Q. Wu, and M. E. Mann, 2013: A gridded reconstruction of warm season precipitation for Asia spanning the past half millennium. J. Climate, 26, 2192-2204, https:// doi.org/10.1175/JCLI-D-12-00099.1.

Fischer, E. M., J. Luterbacher, E. Zorita, S. F. B. Tett, C. Casty, and H. Wanner, 2007: European climate response to tropical volcanic eruptions over the last half millennium. Geophys. Res. Lett., 34, L05707, https://doi.org/10.1029/2006GL027992.

Gao, C., A. Robock, and C. Ammann, 2008: Volcanic forcing of climate over the past 1500 years: An improved ice core-based index for climate models. J. Geophys. Res., 113, D23111, https://doi.org/10.1029/2008JD010239.

Grinsted, A., J. C. Moore, and S. Jevrejeva, 2007: Observational evidence for volcanic impact on sea level and the global water cycle. Proc. Natl. Acad. Sci. USA, 104, 19730-19734, https:// doi.org/10.1073/pnas.0705825104.

Haurwitz, M. W., and G. W. Brier, 1981: A critique of the superposed epoch analysis method: Its application to solar-weather relations. Mon. Wea. Rev., 109, 2074-2079, https://doi.org/ 10.1175/1520-0493(1981)109<2074:ACOTSE >2.0.CO;2.

Haywood, J. M., A. Jones, N. Bellouin, and D. Stephenson, 2013: Asymmetric forcing from stratospheric aerosols impacts Sahelian rainfall. Nat. Climate Change, 3, 660-665, https:// doi.org/10.1038/nclimate1857.

Held, I. M., and B. J. Soden, 2006: Robust responses of the hydrological cycle to global warming. J. Climate, 19, 5686-5699, https://doi.org/10.1175/JCLI3990.1.

Huffman, G. J., R. F. Adler, D. T. Bolvin, and G. Gu, 2009: Improving the global precipitation record: GPCP version 2.1. Geophys. Res. Lett., 36, L17808, https://doi.org/10.1029/ 2009GL040000.

Hurrell, J. W., and Coauthors, 2013: The Community Earth System Model: A framework for collaborative research. Bull. Amer. Meteor. Soc., 94, 1339-1360, https://doi.org/10.1175/BAMS-D12-00121.1.

Iles, C. E., and G. C. Hegerl, 2014: The global precipitation response to volcanic eruptions in the CMIP5 models. Environ. Res. Lett., 9, 104012, https://doi.org/10.1088/1748-9326/9/10/104012.

- , and -2015 : Systematic change in global patterns of streamflow following volcanic eruptions. Nat. Geosci., 8, 838842, https://doi.org/10.1038/ngeo2545.

,,-- A. P. Schurer, and X. Zhang, 2013: The effect of volcanic eruptions on global precipitation. J. Geophys. Res. Atmos., 118, 8770-8786, https://doi.org/10.1002/jgrd.50678.

Khodri, M., and Coauthors, 2017: Tropical explosive volcanic eruptions can trigger El Nino by cooling tropical Africa. Nat. Commun., 8, 778, https://doi.org/10.1038/s41467-017-00755-6.

Li, J., J. Shi, D. D. Zhang, B. Yang, K. Fang, and P. H. Yue, 2017: Moisture increase in response to high-altitude warming evidenced by tree-rings on the southeastern Tibetan Plateau. Climate Dyn., 48, 649-660, https://doi.org/10.1007/s00382016-3101-z.

Liu, F., J. Chai, B. Wang, J. Liu, X. Zhang, and Z. Wang, 2016: Global monsoon precipitation responses to large volcanic eruptions. Sci. Rep., 6, 24331, https://doi.org/10.1038/srep24331.

_ - J. Li, B. Wang, J. Liu, T. Li, G. Huang, and Z. Wang, 2018a: Divergent El Niño responses to volcanic eruptions at different latitudes over the past millennium. Climate Dyn., 50, 37993812, https://doi.org/10.1007/s00382-017-3846-z.

_ C. Xing, L. Sun, B. Wang, D. Chen, and J. Liu, 2018b: How do tropical, Northern Hemispheric, and Southern Hemispheric volcanic eruptions affect ENSO under different initial ocean conditions? Geophys. Res. Lett., 45, 13 041-13 049, https:// doi.org/10.1029/2018GL080315.

Lough, J. M., 2007: Tropical river flow and rainfall reconstructions from coral luminescence: Great Barrier Reef, Australia. Paleoceanography, 22, PA2218, https:/doi.org/10.1029/ 2006PA001377.

Man, W., T. Zhou, and J. H. Jungclaus, 2014: Effects of large volcanic eruptions on global summer climate and East Asian monsoon changes during the last millennium: Analysis of MPI-ESM simulations. J. Climate, 27, 7394-7409, https:// doi.org/10.1175/JCLI-D-13-00739.1.

Mann, M. E., M. A. Cane, S. E. Zebiak, and A. Clement, 2005: Volcanic and solar forcing of the tropical Pacific over the past 1000 years. J. Climate, 18, 447-456, https://doi.org/10.1175/ JCLI-3276.1. 
McGregor, S., A. Timmermann, and O. Timm, 2010: A unified proxy for ENSO and PDO variability since 1650. Climate Past, 6, 1-17, https://doi.org/10.5194/cp-6-1-2010.

Neelin, J. D., 2007: Moist dynamics of tropical convection zones in monsoons, teleconnections, and global warming. The Global Circulation of the Atmosphere, T. Schneider and A. Sobel, Eds., Princeton University Press, 267-301.

_- and I. M. Held, 1987: Modeling tropical convergence based on the moist static energy budget. Mon. Wea. Rev., 115, 3-12, https://doi.org/10.1175/1520-0493(1987)115<0003: $\mathrm{MTCBOT}>2.0 . \mathrm{CO} ; 2$.

Neukom, R., and Coauthors, 2010: Multi-centennial summer and winter precipitation variability in southern South America. Geophys. Res. Lett., 37, L14708, https://doi.org/10.1029/2010GL043680.

_ , and Coauthors, 2014: Multi-proxy summer and winter precipitation reconstruction for southern Africa over the last 200 years. Climate Dyn., 42, 2713-2726, https://doi.org/10.1007/ s00382-013-1886-6.

Oman, L., A. Robock, G. L. Stenchikov, and T. Thordarson, 2006: High-latitude eruptions cast shadow over the African monsoon and the flow of the Nile. Geophys. Res. Lett., 33, L18711, https://doi.org/10.1029/2006GL027665.

Otto-Bliesner, B. L., and Coauthors, 2016: Climate variability and change since $850 \mathrm{CE}$ : An ensemble approach with the Community Earth System Model. Bull. Amer. Meteor. Soc., 97, 735-754, https://doi.org/10.1175/BAMS-D-14-00233.1.

Paik, S., and S.-K. Min, 2017: Climate responses to volcanic eruptions assessed from observations and CMIP5 multi-models. Climate Dyn., 48, 1017-1030, https://doi.org/10.1007/s00382-016-3125-4.

— and - 2018: Assessing the impact of volcanic eruptions on climate extremes using CMIP5 models. J. Climate, 31, 53335349, https://doi.org/10.1175/JCLI-D-17-0651.1.

Pausata, F. S., L. Chafik, R. Caballero, and D. S. Battisti, 2015: Impacts of high-latitude volcanic eruptions on ENSO and AMOC. Proc. Natl. Acad. Sci. USA, 112, 13784-13788, https://doi.org/10.1073/pnas.1509153112.

Peng, Y., C. Shen, W.-C. Wang, and Y. Xu, 2010: Response of summer precipitation over eastern China to large volcanic eruptions. J. Climate, 23, 818-824, https://doi.org/10.1175/2009JCLI2950.1.

Prado, L. F., I. Wainer, and P. L. da Silva Dias, 2018: Tropical Atlantic response to last millennium volcanic forcing. Atmosphere, 9, 421, https://doi.org/10.3390/atmos9110421.

Robock, A., 2000: Volcanic eruptions and climate. Rev. Geophys., 38, 191-219, https://doi.org/10.1029/1998RG000054.

_ 2 2007: Correction to "Volcanic eruptions and climate." Rev. Geophys., 45, RG3005, https://doi.org/10.1029/2007RG000232.

Schneider, D. P., C. M. Ammann, B. L. Otto-Bliesner, and D. S. Kaufman, 2009: Climate response to large, high-latitude and low-latitude volcanic eruptions in the Community Climate System Model. J. Geophys. Res., 114, D15101, https://doi.org/ 10.1029/2008JD011222.

Schneider, U., A. Becker, P. Finger, A. Meyer-Christoffer, M. Ziese, and B. Rudolf, 2014: GPCC's new land surface precipitation climatology based on quality-controlled in situ data and its role in quantifying the global water cycle. Theor. Appl. Climatol., 115, 15-40, https://doi.org/10.1007/s00704-013-0860-x.

Shen, C., W.-C. Wang, Z. Hao, and W. Gong, 2007: Exceptional drought events over eastern China during the last five centuries. Climatic Change, 85, 453-471, https://doi.org/10.1007/s10584-007-9283-y.

,,$-- \ldots$, and,- 2008 : Characteristics of anomalous precipitation events over eastern China during the past five centuries. Climate Dyn., 31, 463-476, https://doi.org/10.1007/ s00382-007-0323-0.
Shi, F., S. Zhao, Z. Guo, H. Goosse, and Q. Yin, 2017: Multi-proxy reconstructions of May-September precipitation field in China over the past 500 years. Climate Past, 13, 1919-1938, https://doi.org/10.5194/cp-13-1919-2017.

Stahle, D. W., and Coauthors, 2016: The Mexican Drought Atlas: Tree-ring reconstructions of the soil moisture balance during the late pre-Hispanic, colonial, and modern eras. Quat. Sci. Rev., 149, 34-60, https://doi.org/10.1016/j.quascirev.2016.06.018.

Stevenson, S., B. Otto-Bliesner, J. Fasullo, and E. Brady, 2016: “El Niño like" hydroclimate responses to last millennium volcanic eruptions. J. Climate, 29, 2907-2921, https://doi.org/10.1175/ JCLI-D-15-0239.1.

, J. T. Fasullo, B. L. Otto-Bliesner, R. A. Tomas, and C. Gao, 2017: Role of eruption season in reconciling model and proxy responses to tropical volcanism. Proc. Natl. Acad. Sci. USA, 114, 1822-1826, https://doi.org/10.1073/pnas.1612505114.

Timmreck, C., 2012: Modeling the climatic effects of large explosive volcanic eruptions. Wiley Interdiscip. Rev.: Climate Change, 3, 545-564, https://doi.org/10.1002/wcc.192.

Trenberth, K. E., and A. Dai, 2007: Effects of Mount Pinatubo volcanic eruption on the hydrological cycle as an analog of geoengineering. Geophys. Res. Lett., 34, L15702, https:// doi.org/10.1029/2007GL030524.

Wang, B., J. Liu, H.-J. Kim, P. J. Webster, and S.-Y. Yim, 2012: Recent change of the global monsoon precipitation (19792008). Climate Dyn., 39, 1123-1135, https://doi.org/10.1007/ s00382-011-1266-z.

Wegmann, M., S. Brönnimann, J. Bhend, J. Franke, D. Folini, M. Wild, and J. Luterbacher, 2014: Volcanic influence on European summer precipitation through monsoons: Possible cause for "years without summer." J. Climate, 27, 3683-3691, https://doi.org/10.1175/JCLI-D-13-00524.1.

Wu, B., T. Zhou, and T. Li, 2017: Atmospheric dynamic and thermodynamic processes driving the western North Pacific anomalous anticyclone during El Niño. Part I: Maintenance mechanisms. J. Climate, 30, 9621-9635, https://doi.org/10.1175/ JCLI-D-16-0489.1.

Yan, Q., Z. Zhang, and H. Wang, 2018: Divergent responses of tropical cyclone genesis factors to strong volcanic eruptions at different latitudes. Climate Dyn., 50, 2121-2136, https:// doi.org/10.1007/s00382-017-3739-1.

Yi, L., H. Yu, X. Xu, J. Yao, Q. Su, and J. Ge, 2010: Exploratory precipitation in north-central China during the past four centuries. Acta Geol. Sin., 84, 223-229, https://doi.org/10.1111/ j.1755-6724.2010.00184.x.

Zanchettin, D., C. Timmreck, H.-F. Graf, A. Rubino, S. Lorenz, K. Lohmann, K. Krüger, and J. H. Jungclaus, 2012: Bi-decadal variability excited in the coupled ocean-atmosphere system by strong tropical volcanic eruptions. Climate Dyn., 39, 419-444, https://doi.org/10.1007/s00382-011-1167-1.

— , and Coauthors, 2016: The Model Intercomparison Project on the Climatic Response to Volcanic Forcing (VolMIP): Experimental design and forcing input data for CMIP6. Geosci. Model Dev., 9, 2701-2719, https://doi.org/10.5194/ gmd-9-2701-2016.

Zhuo, Z., C. Gao, and Y. Pan, 2014: Proxy evidence for China's monsoon precipitation response to volcanic aerosols over the past seven centuries. J. Geophys. Res. Atmos., 119, 6638-6652, https://doi.org/10.1002/2013JD021061.

Zuo, M., W. Man, T. Zhou, and Z. Guo, 2018: Different impacts of northern, tropical, and southern volcanic eruptions on the tropical Pacific SST in the last millennium. J. Climate, 31, 6729-6744, https://doi.org/10.1175/JCLI-D-17-0571.1. 